\title{
1. Investment funds in an era of financialisation
}

\section{A. INTRODUCTION}

Investment fund entities are major equity owners in global capital markets. Institutional investors (such as pension funds, mutual funds and insurance companies carrying out collective investment management) are often referred to in corporate governance literature as universal owners, ${ }^{1}$ and their ownership roles are discussed in relation to time horizons, ${ }^{2}$ passivity ${ }^{3}$ and increasingly, stewardship. ${ }^{4}$ Alternative investment funds such as hedge and private equity funds are regarded differently 5 and opinions as to their ownership and corporate governance roles are still being developed with the emergence of empirical research. ${ }^{6}$ The corporate governance roles of investment fund entities are part and parcel of,

1 J P Hawley and A T Williams, 'Shifting Ground: Emerging Global Corporate-Governance Standards and the Rise of Fiduciary Capitalism' (2005) 37 Environment and Planning 1995-2013, The Rise of Fiduciary Capitalism: How Institutional Investors Can Make Corporate America More Democratic (University of Pennsylvania Press, 2000) generally; Robert A G Monks, The New Global Investors (Capstone, 2001).

2 Aspen Institute, Overcoming Short-termism: A Call for a More Responsible Approach to Investment and Business Management (2009) at http://www. aspeninstitute.org/publications/overcoming-short-termism-call-more-responsibleapproach-investment-business-management.

3 Bernard S Black, "Shareholder Passivity Re-examined" (1990) 89 Michigan Law Review 520; John Hendry, Paul Sanderson, Richard Barker and John D Roberts, 'Owners or Traders? Conceptualizations of Institutional Investors and Their Relationship with Corporate Managers' (2006) 59 Human Relations 1101.

4 UK Stewardship Code 2010, 2012, Japanese Stewardship Code 2014, see 'Japan investors face UK-style financial code', Financial Times (London, 26 Dec 2013); 'Shareholder activism catches fire in Japan', Financial Times (London, 22 June 2014).

5 See Chapter 4, Iris H-Y Chiu, The Foundations and Anatomy of Shareholder Activism (Oxford: Hart, 2010).

6 Alon A Brav, Wei W Jiang, Randall S R S Thomas and Frank F Partnoy, 'Hedge Fund Activism, Corporate Governance and Firm Performance' (2007) at 
or indeed a manifestation of fund investment management strategies and practices, and their growing dominance in global equity markets (and to a lesser extent debt markets).

As we have stated in the Introduction to this book, collective investment fund management is a global phenomenon straddling the private and social paradigms. On the one hand, collective investment fund managements are structures of private mandates and accountability, framed by contract and trust/fiduciary law. On the other hand, the scale of such activities in a financialised era elevates investment management to a dimension of social provision - the management of savings for various real economic needs and the oversight of corporate governance throughout the economy through the acquisition of corporate equity rights.

Regulatory law introduces standards of investor protection and, increasingly, standards on the conduct of such investment management. ${ }^{7}$ How investment management is shaped by both private and regulatory law must, in our view, affect funds' corporate governance roles as part of their management of equity portfolios. Hence, we draw out the governance nexus in the book - the connection between the internal governance of funds and their external corporate governance roles - in order to understand how corporate governance of investee companies is carried out as a part of investment management. This is important as we view the current policy fixation ${ }^{8}$ on the corporate governance role of funds as a panacea for deficient corporate behaviour and perhaps long-term corporate wealth creation in the wider economy to be rather misguided in light of funds' own internal incentives and motivations.

In examining the corporate governance roles of investment funds as primarily arising as a function of their own business imperatives, we first examine the internal governance, structures and incentives of different

http://ssrn.com/abstract=948907; Chris C Clifford, 'Value Creation or Destruction? Hedge Funds as Shareholder Activists' (2007) at http://ssrn.com/abstract= 971018; Marco Becht, Julian Franks, Jeremy Grant and Hannes F Wagner, 'The Returns to Hedge Fund Activism: An International Study' (2014) at http:// papers.ssrn.com/sol3/papers.cfm?abstract_id=2376271.

7 For example, the European Shareholder Rights Directive 2015, Arts 3f-h, see discussion in Iris H-Y Chiu, 'European Shareholder Rights Directive Proposals: Convergence or Divergence from the UK Stewardship Code?', ERA Forum, 2016, forthcoming.

8 E.g. the UK's Stewardship Code, and the EU Shareholder Rights Directive 2017 . 
types of funds, and explore the key characteristics that drive the corporate governance behaviour of each entity examined in this book.

There is substantial extant literature on how the corporate governance role of shareholders is affected by external contextual factors such as legal institutions and legal traditions. The law and finance thesis ${ }^{9}$ may be interpreted as arguing for the importance of minority shareholder protection frameworks in law that shape the corporate governance role of shareholders. The robustness of minority shareholder protection frameworks is important in attracting equity owners, and the corporate governance influence of equity owners may be expressed through securities litigation or corporate governance activism in the US, ${ }^{10}$ or through informal shareholder engagement ${ }^{11}$ or the market for corporate control in the UK. ${ }^{12}$ However we believe that the causal connection between minority shareholder protection frameworks and the corporate governance role of equity-owning funds is an incomplete picture. We observe that internationally active funds play a key part in lobbying for change in the frameworks for minority shareholder protection, such as in Hong Kong. ${ }^{13}$ Thus, such funds are driven to shape as well as respond to the corporate governance environment they are in. The study of internal governance factors may be of crucial importance in ultimately understanding how funds conceive of their corporate governance role.

9 R La Porta, F Lopez-de-Silanes, A Shleifer and R Vishny, 'Law and Finance' (1998) 106 Journal of Political Economy 1113; R La Porta, F Lopez-de-Silanes and A Shleifer, 'What Works in Securities Laws' (2006) 71 Journal of Finance 1.

10 Steven A Ramirez, 'The Virtues of Private Securities Litigation: An Historic and Macroeconomic Perspective' (2014) 5 Loyola University of Chicago Law Journal 669; Martin Gelter, 'The Pension System and the Rise of Shareholder Primacy' (2013) 43 Seton Hall Law Review 909.

11 Iris H-Y Chiu, 'A Confidence Trick: Ex Ante versus Ex Post Frameworks in Minority Investor Protection in the UK' (2014) 11 European Company Law 6.

12 The liberal takeovers regime in the UK is discussed in John Armour and David Skeel Jnr, 'Who Writes the Rules for Hostile Takeovers, and Why - The Peculiar Divergence of US and UK Takeover Regulation' (2006) 95 Georgetown Law Journal 1727, who argue that the UK regime is self-regulatory in nature and therefore was susceptible to institutional investor influence from early on.

13 Roger Barker and Iris H-Y Chiu, 'Protecting Minority Shareholders in Blockholder-Controlled Companies - Evaluating the UK's Enhanced Listing Regime in Comparison with Investor Protection Regimes in New York and Hong Kong' (2015) Capital Markets Law Journal, forthcoming. 
Funds' corporate governance roles have over the years been discussed and theorised by various commentators in law, economics and business. Below is a brief survey of the key milestones in the literature.

\section{Literature Review of Funds' Corporate Governance Roles}

The phenomenon of institutional share-ownership and its implications has already been noted by commentators more than a decade ago. In the early 1990 s, Useem ${ }^{14}$ discerned that equity ownership of publicly traded corporations in the US was falling into the hands of funds as intermediary owners. He also noted that these intermediary owners had started to adopt a unique corporate governance role which he termed investor capitalism, a movement that sees the rise of investor say and power in how corporations are run. The assumption of investors' corporate governance role as 'owners' is not normatively questioned, largely because of the legal fabrication of shareholders' rights as quasiproprietary in nature. ${ }^{15}$ Hence the legitimacy or credibility of investor capitalism in the form of shareholder activism has not been disputed in principle, but has been examined from the perspective of outcome efficiency - whether activism improves financial performance of companies (albeit mainly from a shareholder perspective). ${ }^{16}$

14 Michael Useem, Investor Capitalism: How Money Managers are Rewriting the Rules of Corporate America (Basic Books, 1999).

15 See Sanford J Grossman and Oliver D. Hart, 'The Costs and Benefits of Ownership: A Theory of Vertical and Lateral Integration' (1986) 94 Journal of Political Economy 691-719; Chapter 4, Iris H-Y Chiu, The Foundations and Anatomy of Shareholder Activism (Oxford: Hart, 2010); John Armour and Michael Whincop, 'The Proprietary Foundations of Corporate Law' (2007) Oxford Journal of Legal Studies 429.

16 This is a landscape of mixed results, for pension fund activism, see Jonathan MJM Karpoff, 'The Impact of Shareholder Activism in Target Companies: A Survey of Empirical Findings' (Sep 2001) at http://ssrn.com/abstract= 885365; Stuart Gillan and Laura T Starks, 'The Evolution of Shareholder Activism in the United States' (2007) at http://papers.ssrn.com/sol3/ papers.cfm?abstract_id=959670. The results are mixed in Europe too, see JeanMichel Sahut, Jean-Sebastien Lantz and Sophie Montandrau, 'Activism of Institutional Investors, Corporate Governance Alerts and Financial Performance' (2010) 15 International Journal of Business 221 at http://papers.ssrn.com/sol3/ papers.cfm?abstract_id=1735797. Mixed results apply too for hedge funds, see fnt 6 and Lucian A Bebchuk, Alon A Brav and Wei Jiang, 'The Long Term Effects of Hedge Fund Activism' (2013) at http://papers.ssrn.com/sol3/papers. cfm?abstract_id=2291577. 
Further, Useem opines that investor capitalism brings about the democratisation of participation in corporate wealth creation, as equity-owning institutional shareholders represent their myriad individual beneficiaries, many of whom are ordinary, saving citizens. Investor capitalism is seen as a form of democratic capitalism, lauded by many commentators as a triumphant form of economic organisation. ${ }^{17}$ Hawley and Williams ${ }^{18}$ also framed the ownership of corporate equity by institutional funds as ushering in an age of 'fiduciary capitalism' as financial intermediaries act in their corporate governance roles in a representative capacity for myriad savers, democratising the corporate governance process and bringing about the promising prospects of long-term and responsible forms of capitalism under such 'universal ownership'. In many respects, such authors have viewed fund managers as more acceptable representatives of capital than earlier generations of capitalist (e.g. the industrialists or robber barons of the nineteenth century), who were more easily characterised as elitist or exploitative of other stakeholders.

However, more recent commentators have noted that investor or fiduciary capitalism is more correctly described as a form of agency capitalism, ${ }^{19}$ intermediary capitalism $^{20}$ or money manager

17 J P Hawley and A T Williams, The Rise of Fiduciary Capitalism: How Institutional Investors Can Make Corporate America More Democratic (University of Pennsylvania Press, 2000); John C Coffee, Jnr, 'The Future as History: The Prospects for Global Convergence in Corporate Governance and Its Implications' (1999) 93 Northwestern University Law Review 641; Henry Hansmann and Reinier Kraakman, 'The End of History for Corporate Law' (2000) 89 Georgetown Law Journal 439; which views were defended in a nuanced manner in Henry Hansmann, 'How Close is the End of History' (2005) at http://lesliecaton.com/wordpress/wpcontent/uploads/2012/01/7-Hansmann-FINAL.pdf; and in Hansmann and Kraakman, 'Reflections on the End of History for Corporate Law' (2011) at http:// papers.ssrn.com/sol3/papers.cfm?abstract_id=2095419.

18 J P Hawley and A T Williams (2000), above.

19 Gilson and Gordon describe this phenomenon as a reconcentration of ownership in the hands of intermediaries acting as agents for myriad beneficiaries, Ronald J Gilson and Jeffrey N Gordon, 'Agency Capitalism: Further Implications of Equity Intermediation' (2014) at http://ssrn.com/abstract= 2359690.

20 As a form of intermediary capitalism, it is perhaps arguable that shareholder rights would not necessarily be exercised as it depends on the costs and benefits of the intermediary undertaking this role. The intermediary's business model and incentives affect the undertaking or otherwise of shareholder roles. See Paul H Edelman, Randall S Thomas and Robert B Thompson, 'Shareholder Voting in an Age of Intermediary Capitalism' (2014) at http://ssrn.com/abstract= 2401746 arguing that shareholder rights such as voting should only be exercised 
capitalism. $^{21}$ Beneficial owners are a few steps removed from acting as 'shareholders', as power over investment assets is predominantly exercised by intermediaries. ${ }^{22}$ Intermediary institutions choose whether or not to participate in corporate governance roles, giving rise to 'agency aspects' of the intermediary-beneficiary relationship. ${ }^{23}$ Beneficiaries can only rely on accountability frameworks that govern their relationships/ mandates with funds in contract, trust or corporate law, ${ }^{24}$ and these bodies of law have not articulated precisely in relation to the aspect of fund management that relates to intermediaries' assumption of corporate governance roles in their investee companies.

Agency, intermediary or money manager capitalism is a phenomenon that arises out of the increasing power of the intermediary sector in amassing financial capital and allocating financial flows. ${ }^{25}$ Such intermediaries effectively become the primary representatives of capital, and assume all of the powers and privileges inherent in the legal ownership of corporate equity. The growth of the intermediary sector - and the declining influence of the beneficial owners of capital - is part of the larger phenomenon of financialisation. ${ }^{26}$ Financialisation can be used as a

for reasons of efficiency such as monitoring when their immediate interest tied to residual value is affected or when the Board is conflicted, and when voting is an efficient mechanism for aggregating heterogeneous preferences when the decision differentially affects shareholders and no 'correct' decision is in issue.

21 Wray quotes Minsky and describes this as a phenomenon of concentrated allocation of investment and savings capital to investment funds that insularly chase ever-higher returns oblivious to the risks, especially systemic risks, they pursue. See L Randall Wray, 'Money Manager Capitalism and the Global Financial Crisis' (2009) at http://ssrn.com/abstract=1478508.

22 It is argued that beneficial owners are not excluded from the corporate governance process under precepts in trust and fiduciary law. See Ewan McGaughey, 'Does Corporate Governance Exclude the Ultimate Investor?' (2016) 16 Journal of Corporate Law Studies 221. However, modern 'agency capitalism' interposes a number of layers in terms of relationship with investee companies and the exercise of corporate governance rights. Hence it would be rather simplistic to treat beneficial owners as 'shareholders'.

23 Gilson and Gordon, 'Agency Capitalism' (2014), above.

24 See survey in John K Thompson and Sang-Mok Choi, 'Governance Systems for Collective Investment Schemes in OECD Countries' OECD Occasional Paper (April 2001).

25 Jonathan Nitzan and Shimshon Bichler, Capital as Power: A Study of Order and Creorder (Oxford: Routledge, 2009) argues that capital begets accumulation as an end in itself.

26 To be explored shortly. 
descriptive concept which reflects the growing overall influence of the private financial sector. Alternatively, it can be used to define a normative ideology that views the finance sector as an efficient and desirable means of navigating economic life, and which welcomes its growing role in addressing an ever wider range of economic and social needs.

We adopt the broad term 'financier capitalism' to describe the real world implementation of the ideology of financialisation. Furthermore, we believe that investment fund entities' business models and governance structures have to be understood against the wider backdrop of financialisation. Fund entities' business models and governance structures in turn influence funds' corporate governance roles in the ownership of corporate equity. In Section D below, we argue that fund entities' internal governance is heavily influenced by both market forces and law and regulation, such law and regulation responding to and catering for the needs generated by financialisation. Further, these, in conjunction with recent developments in UK and EU policy framing institutional investors' corporate governance role as 'stewardship', ${ }^{27}$ determine the corporate governance roles they assume.

This book intends to go some way in raising questions regarding the legitimacy of funds' corporate governance roles, whether framed as engagement, stewardship or activism. ${ }^{28}$ The internal governance, structures and incentives that we discern raise questions regarding the appropriateness of corporate ownership activities undertaken by institutional investors within the quasi-proprietary paradigm of share ownership. The examination of internal governance, structures and incentives could also raise questions as to the continued appropriateness of retaining shareholder primacy over the residual control rights and privileges attached to the ownership of corporate equity, given that increasingly it is funds that are the main actors responsible for exercising such rights. ${ }^{29}$

27 Iris H-Y Chiu, 'Turning Institutional Investors into "Stewards" - Exploring the Meaning and Objectives of "Stewardship"” (2013) Current Legal Problems 1 .

28 See Introduction; also Iris H-Y Chiu, The Foundations and Anatomy of Shareholder Activism (Oxford: Hart, 2010); the adoption of language of 'stewardship' and 'engagement' in the UK context, as distinguished from 'activism' in the US context. On the meaning of stewardship, see Iris H-Y Chiu (2013), above.

29 Which was doubted very much by Berle and Means, in pp. 66-69, The Modern Corporation and Private Property (NY: Macmillan, 1932). 
This chapter proceeds as follows: first, we provide an account of the growth of collective investment management as a phenomenon in financialisation and unpick the characteristics of such financialised investment management. We then point out the role of private and regulatory law in shaping its practices and behaviour. We then turn to the issue of why funds own corporate equity and how their positions as shareholders are treated in the rubric of investment management. This chapter sets the context for examining how corporate governance roles undertaken by funds are an instrumental facet of their own business imperatives and must be understood in that light. This is important as the likely corporate governance role of funds should not be idealised, taken out of context or misunderstood by policy makers.

\section{B. GROWTH OF COLLECTIVE INVESTMENT MANAGEMENT}

The OECD reports that growth in collective investment management has been remarkable since the early 1990s. ${ }^{30}$ The Price Waterhouse Coopers survey $^{31}$ of Asset Management reports that global assets under management stand at about USD\$64 trillion at the end of 2013.32 That relates to assets managed by professional asset managers and does not include those managed in-house. In terms of pensions, as of 2012 total assets under collective management in global pensions (where data has been available) stand at approximately USD $\$ 30$ trillion, total assets managed by insurance companies at approximately USD $\$ 24$ trillion and total assets managed by other investment funds at approximately USD \$22 trillion. ${ }^{33}$ Alternative investment fund assets are estimated to stand at

30 John K Thompson and Sang-Mok Choi, 'Governance Systems for Collective Investment Schemes in OECD Countries' OECD Occasional Paper (April 2001).

31 PwC, Asset Management 2020: A Brave New World (2013) at http:// www.pwc.com/gx/en/asset-management/publications/asset-management-2020-abrave-new-world.jhtml; In Europe, assets under management, including pensions, stood at 13.8 trillion euros at the end of 2011, see EFAMA, Asset Management in Europe: 6th Annual Review (2013) at http://www.efama.org/Publications/ Statistics/Asset\%20Management\%20Report/Asset_Management_Report_2013.pdf.

32 See Andy Haldane's speech estimating global assets managed by institutions to be at USD $\$ 87$ trillion, at http://www.bankofengland.co.uk/publications/ Documents/speeches/2014/speech723.pdf.

33 http://www.oecd.org/finance/private-pensions/globalpensionstatistics.htm. 
more than USD $\$ 2$ trillion. ${ }^{34}$ In 2014, Haldane estimated a figure of total global assets managed by insurance companies, pension funds, mutual funds and others as representing about twice the size of global gross domestic product. ${ }^{35}$ Asset managers are estimated in 2017 to have over $£ 4$ trillion of UK savings under management in retail and pension funds combined. ${ }^{36}$

The growth of collective investment management is a global phenomenon, although the US and the UK have emerged as the leading geographical locations for the main players in the sector. ${ }^{37}$ The key contributing factor to this growth is the rise of pension fund management for retirement savings, making savings work through investment in securities assets. ${ }^{38}$ Walter and Sisli ${ }^{39}$ refer to the collective investment management of pension funds as a form of partial intermediation as funds flow into managed portfolios of assets instead of being entrusted to banks that perform a full intermediation service (i.e. offering financial claims against themselves in exchange). Pension fund management from both developed countries ${ }^{40}$ and emerging economies ${ }^{41}$ accounts for the lion's share of global assets under management. In the UK, Congdon documents the institutionalisation of savings starting as early as in the 1960s. ${ }^{42}$

34 Based on Deutsche Bank's 2014 Alternative Investment Survey at https:// www.db.com/medien/en/content/4666_4819.htm.

35 Andrew Haldane, 'The Age of Asset Management', speech at London Business School (4 April 2014), see fnt 32 above.

36 FCA, Asset Management Market Study Final Report (28 June 2017) at para 1.2, at https://www.fca.org.uk/publication/market-studies/ms15-2-3.pdf.

37 http://www.theinvestmentassociation.org//assets/files/research/2016/20160 929-amsfullreport.pdf p. 15.

38 Gordon L Clark, 'Institutional Investors and Risk Management' in Gordon L Clark, Adam D Dixon and Ashby HB Monk (eds), Managing Financial Risks: From Global to Local (Oxford: OUP 2012) at Chapter 3.

39 Ingo Walter and Elif Sisli, 'The Asset Management Industry in Asia: Dynamics of Growth, Structure, and Performance' (2007) 16 Financial Markets, Institutions and Instruments 1.

40 Carmen-Pilar Martí-Ballester, 'A Comparative Analysis of the Performance of Collective Investment Institutions' (2012) Review of Economics and Finance forthcoming.

41 Ramón Moreno and Marjorie Santos, 'Pension Systems in EMEs: Implications for Capital Flows and Financial Markets' (2009) at http://ssrn.com/ abstract $=1992376$.

42 Chapter 2, Tim Congdon, Money and Asset Prices in Boom and Bust (London: Institute of Economic Affairs, 2005). 
The savings glut from current account surplus countries ${ }^{43}$ also contribute to the rise in capital available for investment; these may come from sovereign savings, much of which is managed collectively in sovereign wealth funds, and savings from increasingly wealthy middle classes ${ }^{44}$ channelled into retail sector collective investment schemes, ${ }^{45}$ or even alternative investment funds. ${ }^{46}$ There is also a proportion of the very wealthy private banking clients who channel savings into professionally managed collective investment funds in order to benefit from management brand and expertise in wealth structuring for tax advantages, wealth protection and search for yield. ${ }^{47}$ The growth of the high net worth individual sector, especially from emerging economies, is expected to be significant, and Price Waterhouse Coopers predicts that the sector may contribute to as much as two-thirds of investable capital. ${ }^{48}$ The increasing popularity of investment as a means to meet a range of financial needs for the sophisticated and the ordinary is supported by (a) policy changes such as shifting the risks of retirement provision to the individual away from the state or employers and (b) macro-economic conditions of cheap money, ${ }^{49}$ financial stability and rising asset prices ${ }^{50}$ in developed jurisdictions such the US, UK and parts of Europe.

43 Martin Wolf, Fixing Global Finance (Conn: Yale University Press, 2008); Chapter 6, Niall Ferguson, The Ascent of Money (London: Penguin, 2008).

44 Tetsuya Kamiyama, 'ASEAN's Investment Trusts Market: Current Conditions and Challenges' (2013) 5 Nomura Journal of Capital Markets 1.

45 Such as unit trusts in the UK, mutual funds in the US and the European UCITs.

46 Hedge and private equity funds.

47 Ingo Walter and Elif Sisli, 'The Asset Management Industry in Asia: Dynamics of Growth, Structure, and Performance' (2007) 16 Financial Markets, Institutions and Instruments 1.

48 Price Waterhouse Coopers, Asset Management 2020: A Brave New World (2014) at http://www.pwc.com/gx/en/asset-management/publications/assetmanagement-2020-a-brave-new-world.jhtml.

49 David Roche and Bob McKee, New Monetarism (Independent Strategy, 2007).

50 See Franklin Allen and Douglas Gale, 'Asset Price Bubbles and Monetary Policy' (2000) at http://finance.wharton.upenn.edu/ allenf/download/Vita/apbm. pdf; Thomas I Palley, Financialisation: The Economics of Finance Capital Domination (Basingstoke: Palgrave Macmillan 2013); Robert W Parenteau, 'The Late 1990s US Bubble: Financialization in the Extreme' in Gerald A Epstein (ed.), Financialization and the World Economy (Cheltenham: Edward Elgar, 2005) at p. 111. 
The collective investment management industry has arisen to meet the need for savings management. ${ }^{51}$ Fund houses arise to compete with banks in the intermediation business and provide more choice to savers and investors. ${ }^{52}$ Although the partial intermediation offered by fund houses results in greater risk taking by investors and savers, as risk is not absorbed by fully intermediating institutions such as banks, greater choice and chance of higher yields have become attractive to savers and investors. Collective investment management has become a staple form of financial intermediation for the sophisticated as well as the ordinary. ${ }^{53}$ Further, fund owners are increasingly delegating portfolio management to the professional asset management industry, ${ }^{54}$ creating another link in the chain of intermediation. ${ }^{55}$ The Price Waterhouse Coopers survey predicts that by 2020, global assets under management will exceed USD $\$ 100$ trillion. ${ }^{56}$ Financier Capitalism has become a global phenomenon with increasingly developed and mature business models.

The next Section argues that the collective investment management industry has to be understood against the backdrop of financialisation and its practices reflect the normative ideology of financialisation as a positive and efficient development.

\section{FINANCIER CAPITALISM AS HALLMARK IN THE AGE OF FINANCIALISATION}

As mentioned above, the collective investment management industry has been described as ushering in an age of agency, intermediary or money manager capitalism. Financier Capitalism is a shorthand that captures a broad amalgamation of what has been discussed in academic literature. Intermediary capitalism as Edelman et $\mathrm{al}^{57}$ describe it, refers to standing inbetween ultimate savers and asset markets. However, the mode of

51 Mary Mellor, The Future of Money: From Financial Crisis to Public Resource (New York: Pluto Press 2010).

52 Arthur E Wilmarth Jnr, 'The Transformation of the Financial Services Industry: 1975-2000, Competition, Consolidation and Increased Risks' (2002) University of Illinois Law Rev 215.

53 Ingo Walter and Elif Sisli (2007), above.

54 Haldane, 'The Age of Asset Management' (2014), above.

55 Howard Gospel, Andrew Pendleton and Sigurt Vitols, Financialization, New Investment Funds and Labour (Oxford: OUP 2014) at p. 21. This will be discussed in greater detail in Chapter 2.

56 Price Waterhouse Coopers, Asset Management 2020 (2014), above.

57 Edelman et al, 'Shareholder Voting' (2014), above. 
standing inbetween creates agency costs, as Gilson and Gordon 58 point out, and the very activity of managing or being in control of someone else's money creates incentives and motivations in terms of how the activity is carried out as a business. ${ }^{59}$

Clark has described the age of financial intermediaries as the 'third stage' of capitalism. ${ }^{60}$ The passage towards the age of financial intermediaries was an experience of atomisation of economic activity. From the rise of the entrepreneur and the production of economic activity, economic activity experienced atomisation in the form of separation of ownership from control under the structure of the corporate form, ${ }^{61}$ allowing the rise of professional corporate managers. Subsequently, atomisation in the form of separation of capital supply from investment takes place, allowing the rise of investment management intermediaries. Savers and investors relinquish their decisions to such intermediaries, and the role of such intermediaries is framed by client protection standards and/or regulation. The atomisation processes in the passage towards financier capitalism has created an industry devoted to investment. Such specialisation could potentially be economically efficient for mobilising and allocating resources to productive entrepreneurship in the corporate sector. ${ }^{62}$ On the other hand, the creation of an industry devoted to amassing investment capital and having the discretionary power to allocate such capital and profit from such activity introduces a unique set of incentives and motivations to the industry, and these could perpetuate self-serving or rent-seeking ends.

Financier capitalism is a manifestation of the financialisation of economic life. Financialisation has been defined as 'the increasing role of financial motives, financial markets, financial actors and financial institutions in the operation of the domestic and international economies', ${ }^{63}$ or in a political scientist's view, 'financialisation is the increase in the influence of financial markets, institutions and elites over both the

58 Gilson and Gordon, 'Agency Capitalism' (2014), above.

59 Wray, 'Money Manager Capitalism' (2009), above.

60 Robert C Clark, 'The Four Stages of Capitalism: Reflections on Investment Management Treatises' (1981) 94 Harvard Law Review 561.

61 Clark, 'The Four Stages' (1981), above, quoting Berle and Means, The Modern Corporation (1932), above.

62 Making equity markets work for savers and corporations is the vision in the Kay Review, BIS, The Kay Review of UK Equity Markets and Long-Term Decision Making (Final Report, 23 July 2012).

63 Gerald A Epstein, 'Introduction: Financialization and the World Economy' in Gerald A Epstein ed., Financialization and the World Economy (Cheltenham: Edward Elgar, 2005) at p. 3. 
economy and other institutions of society, including the government.' 64 The increasing importance of finance may be observed in steady increases in GDP accounted for by the financial sector in the $\mathrm{US}^{65}$ as well as Europe. ${ }^{66}$ In the UK, the Bank of England ${ }^{67}$ noted that financial sector output has grown exponentially, although a dip occurred during the period of the global financial crisis 2007-09. In both the US and UK, financial sector output accounts for about just under 10 per cent of GDP. Besides hard figures showing the economic importance of finance, the permeation of finance has occurred in commercial and in everyday life in terms of the use of financial services and products to address a wide range of commercial and social needs.

Van der Zwan ${ }^{68}$ argues that financialisation literature mainly deals with three important aspects of the phenomenon: the encouragement of financial accumulation by private individuals, the shareholder value revolution in corporate governance and the permeation of private sector financial solutions into everyday life. The rise of financier capitalism embodies each of these features. First, retail sector savings are encouraged and amassed and professionally managed in order to become the staple mechanism for meeting 'everyday life' needs. Second, such professional management channels savings into investment capital which is used for profit generation through financial instruments and transactions. Financier capitalism then fundamentally affects how corporations, which are at the same time wealth generating productive entities and investible assets on the market, are to be managed and run.

Financier capitalism is supported by the legitimisation of certain 'financialisation norms', which have increasingly embedded themselves into public opinion and social attitudes. The broad context of the norms of financialisation are important for our understanding of supporting law

64 Gautam Mukunda, 'The Price of Wall Street's Power' (2014) Harvard Business Review 70, on the effects of financialisation upon the American economy.

65 Thomas Philippon, 'Has the U.S. Finance Industry Become Less Efficient? On the Theory and Measurement of Financial Intermediation' (2012) at http://pages.stern.nyu.edu/ tphilipp/papers/Finance_Efficiency.pdf.

66 Guillaume Bazot, 'Financial Consumption and the Cost of Finance: Measuring Financial Efficiency in Europe (1950-2007)' (2014) at http://www.ipp. eu/wp-content/uploads/2014/06/working-paper-2014-17-pse-gbazot.pdf.

67 Stephen Burgess, 'Measuring Financial Sector Output and Its Contribution to UK GDP', Quarterly Bulletin Q3 (2011) at http://www.bankofengland. co.uk/publications/Documents/quarterlybulletin/qb110304.pdf.

68 Natascha van der Zwan, 'Making Sense of Financialisation' (2014) 12 Socio-economic Review 99. 
and regulation for this socio-economic model, and these in turn are fundamental to understanding how collective investment fund entities are internally governed. This Section draws out seven such 'financialisation norms' upon which financier capitalism is based.

The seven 'financialisation norms' are: (a) belief in the social importance of investment in financial assets by private individuals; (b) making investment efficient through collective pooling and management; (c) the professionalisation of collective management in portfolio management; (d) making the realisation of investment returns a business and profitoriented activity; (e) the commoditisation of investible subject matter as asset classes; (f) detachment of investment returns from real productive activity (or the lack of necessary connection between the two); and (g) the widespread acceptance of financial risk-bearing by society. The following elaborates.

\section{(a) Belief in the Social Importance of Investment in Financial Assets by Private Individuals}

'Saving' is defined in a mainstream dictionary as the portion of income that is not spent or used immediately. ${ }^{69}$ In an era of financialisation, an efficient savings strategy is increasingly seen as implying investment in financial assets, ${ }^{70}$ which offers the individual the potential of fulfilling a variety of future needs. Erturk et $\mathrm{al}^{71}$ describe financialisation as championing a form of democratic participation for households in the investment market, giving opportunities to and empowering households - and no longer just a small number of wealthy individuals - to be engaged in wealth generation through saving in investment. Langley ${ }^{72}$ further opines that financialisation underpins the neo-liberal move away from social welfarism to self-care and individual responsibility, promoting the adoption of investing as one of the new liberating technologies that would help the individual realise her power and responsibility in organising her own financial choices and affairs.

\footnotetext{
69 Merriam Webster online at https://www.merriam-webster.com/.

70 Gerald F Davis, Managed by the Markets: How Finance Re-shaped America (New York: OUP, 2009) at p. 18.

71 Ismail Erturk, Julie Froud, Sukhdev Johal, Adam Leaver and Karel Williams, 'The Democratization of Finance? Promises, Outcomes and Conditions' (2007) 14 Review of International Political Economy 553.

72 Paul Langley, 'Uncertain Subjects of Anglo-American Financialization' (2007) 65 Cultural Critique 67.
} 
The free market for investment promises choice for the deployment of savings into investments that could generate returns to meet an individual's future needs and circumstances. Hence, social needs that need to be met in the future such as ownership of home, consumption of higher education for children and provision in retirement are funnelled into saving through investment. The ramification is that savers would increasingly see investment in financial assets as being the only means to meet the social needs of saving, therefore relying on the investment industry to provide a quasi-necessary good. The investment industry thus moves away from catering for the luxury good of discretionary investment for an elite stratum of society, to providing a quasi-necessary good of investment that realises the social expectations imbued in saving for society as a whole.

However, investment in financial assets generates income and returns not merely by funding real economic productivity but by trading. Returns generated by trading in the markets have been observed in empirical research and in real life often to surpass wealth created by real productive economic activity. ${ }^{73}$ Empirical research ${ }^{74}$ shows significant income inequalities between finance-generated income and non-finance generated income from real productive economic activity. The potential of realising huge paper gains, therefore, further stimulates the startling ascendancy of investment in financial assets as a potential wealth generating activity for individual savers.

The growing belief in the importance of investment in financial assets by private individuals has the following ramifications: (i) social trust in financier capitalism and the increasing distancing of economic agents

73 Robert Boyer, 'Is a Finance-led Growth Regime a Viable Alternative to Fordism?' (2000) 29 Economy and Society 111; Greta Krippner, 'Accumulation and the Profits of Finance' in Ismail Erturk, Julie Froud, Sukhdev Johal, Adam Leaver and Karel Williams (eds), Financialization At Work: Key Tests and Commentary (Oxford: Routledge, 2008).

74 Basak Kus, 'Financialisation and Income Inequality in OECD Nations: 1995-2007' (2012) 43 The Economic and Social Review 477; Gerald Epstein and Arjun Jayadev, 'The Rise of Rentier Incomes in OECD Countries: Financialization, Central Bank Policy and Labor Solidarity' in Gerald A Epstein ed., Financialization and the World Economy (Cheltenham: Edward Elgar, 2005) at p. 46; Ken-Hou Lin and Donald Tomaskovic-Devey, 'Financialization and U.S. Income Inequality, 1970-2008' (2013) 118 American Journal of Sociology 1284; Gerard Dumenil and Dominique Levy, 'Financialization, Neo-liberalism and Income Inequality in the USA' in Ismail Erturk, Julie Froud, Sukhdev Johal, Adam Leaver and Karel Williams (eds), Financialization At Work: Key Tests and Commentary (Oxford: Routledge, 2008). 
from managing key features of their economic life; (ii) increasing social importance of financier capitalism, with increasing power in the hands of financial intermediaries managing increasing amounts of capital supply; (iii) changes in the balance of economic activity in the corporate sector between real productivity and financial sector activity; and (iv) increasing wealth disparities resulting from the ability to participate in financial market trading and speculation. ${ }^{75}$ These are discussed further shortly.

The dominant structure that has arisen for investment intermediation is the organisation of savings into pooled collective investment vehicles managed by collective investment entities.

\section{(b) Making Investment Efficient through Collective Pooling and Management}

The organisation of savings into collective pooled investment vehicles is a phenomenon in efficiency as well as in power. Collective pooling of savings into investment funds ensures sufficiently affordable access to investment due to economies of scale. But this gives rise to standardisation in the relational dimension between investment intermediaries and saver-beneficiaries, and therefore (ironically) less prospect for tailormade financial solutions to specific needs.

Erturk et al ${ }^{76}$ critically describes the rise in collective investment management as a form of 'coupon pool' capitalism where the masses become feedstock for finance. Individual beneficiaries meeting their economic and social needs become digitised as units of capital supply. Dembinski ${ }^{77}$ argues that financialisation is characterised by the transactionalisation of relationships, tending to be narrowly focused and transient.

The rising tide of capital encourages investment intermediaries to compete for capture of market share, and to engage in marketing and branding in order to attract financial flows. As Bogle ${ }^{78}$ opines, the rise in collective pooling and management of investment capital has focused

\footnotetext{
75 See above.

76 Ismail Erturk, Julie Froud, Sukhdev Johal, Adam Leaver and Karel Williams, 'Financialisation, Coupon Pool and Conjuncture' in Ismail Erturk, Julie Froud, Sukhdev Johal, Adam Leaver and Karel Williams (eds), Financialization At Work: Key Tests and Commentary (Oxford: Routledge, 2008).

77 Paul H Dembinski, Finance: Servant or Deceiver (trans. by Kevin Cook, Basingstoke: Palgrave Macmillan 2009).

78 John C Bogle, Common Sense on Mutual Funds (Chichester: John Wiley \& Sons, 2011) at pp. 425ff.
} 
investment intermediaries' minds upon capturing as much as possible of the supply of capital, instead of managing such capital as stewards for the needs of the beneficiaries. Despite a lack of supportive empirical evidence, the industry has been highly successful in persuading both private and institutional clients that past fund performance is in some way indicative of future fund performance. ${ }^{79}$ In contrast, stewardship activities vis-à-vis investee companies are often treated as relatively insignificant feature of funds' marketing efforts.

Increased accumulation entails a wider breadth of discretionary power over the use and allocation of accumulated capital, ${ }^{80}$ in turn sharpening an appetite ${ }^{81}$ for further accumulation of capital and power. It also feeds through directly to the profitability of investment management business entities due to the ad valorem fee structure of many funds whereby customer revenues are determined by the magnitude of assets under management. Further, accumulation can be further magnified by turning to leverage ${ }^{82}$ which provides a multiplier effect on potential gains.

It may be argued that forces of competition and anti-trust regulation are crucial in preventing the rise of substantial disparity of power between the investment intermediaries who are in control of the amassed capital and diffused savers. However research ${ }^{83}$ has shown that fund outperformers tend to attract a disproportionate amount of capital flows, and this also gives rise to issues of potential systemic risk due to the

79 Financial Conduct Authority, 'Asset Management Market Study'. Interim Report, November 2016. MS15/2.2, p. 52.

80 John Scott, Power: Key Concepts (Cambridge: Citizenry Press, 2001) at pp. $48,73$.

81 Jonathan Nitzan and Shimshon Bichler, Capital as Power: A Study of Order and Creorder (Oxford: Routledge, 2009) argues that the inherent tendencies of owners or controllers of capital are to accumulate more in order to exercise power. Peter Pelzer, 'Risk as Present Futures: An Elaboration on Risk and Fear' in Susan Long and Burkard Sievers (eds), Towards a Socioanalysis of Money, Finance and Capitalism (Oxford: Routledge, 2013) at p. 149 describes the tendencies towards accumulation as an instinct towards the transcendental or god-likeness.

82 Margaret M Blair, 'Making Money: Leverage and Private Sector Money Creation' (2012) 36 Seattle University Law Review 417; Mary Mellor, The Future of Money: From Financial Crisis to Public Resource (New York: Pluto Press 2010), but see Tim Congdon, Money and Asset Prices in Boom and Bust (London: Institute of Economic Affairs, 2005) who argues that credit does not, strictly speaking, increase the money supply even if the same consequences, such as inflation of asset prices, result.

83 'Just 150 will Control UK Funds', Financial Times (London, 29 June 2014). 
sheer size and economic importance of certain funds in global asset markets. ${ }^{84}$ The forces of competition also appear to be limited in finance as financial institutions build up linkages and connections sprawling global geographies in order to trap global financial flows, accumulate capital and power, ${ }^{85}$ and entrench the centrality of finance in social and political consciousness. ${ }^{86} \mathrm{~A}$ recent market study of investment management by UK regulators showed that, although there are relatively large numbers of participants in the sector, this does not translate into a high level of price competition that might be of benefit to consumers. Indeed, profit margins in the sector were found to be persistently amongst the highest of any sector in the UK economy. ${ }^{87}$

Gospel et $\mathrm{al}^{88}$ note that one of the consequences of financialisation is the lengthening of the intermediary chain and an increase in the financial actors who are able to cream off fees and charges to themselves. Such intermediaries may include fund operators, fund managers, custody banks, brokerage and research providers, securities lending providers, investment consultants and online investment platforms, to name but a few. Hence, the division of labour in finance has produced complex chains of linked firms, services and industries that are in a position to influence investment practice in a manner that is not necessarily aligned with principles of sound corporate ownership. The inter-dependencies in finance are now being studied in an attempt to understand the nature of

84 Haldane, 'The Age of Asset Management' (2014), above; E Bengtsson, 'Fund Management and Systemic Risk - Lessons from the Global Financial Crisis' (Cityperc Working Paper 2013); Office of Financial Research, Asset Management and Financial Stability (Sep 2013) at http://www.treasury.gov/ initiatives/ofr/research/Documents/OFR_AMFS_FINAL.pdf; Douglas J Elliott, 'Systemic Risk and the Asset Management Industry' (Brookings Institute, May 2014) at http://www.brookings.edu/ /media/research/files/papers/2014/ 05/systemic\%20risk\%20asset\%20management\%20elliott/systemic_risk_asset_ management_elliott.pdf; Massimo Massa, David Schumacher and Yan Wang, 'Who's Afraid of BlackRock?' (2015) at http://papers.ssrn.com/sol3/papers.cfm ?abstract_id=2641078.

85 Gordon L Clark and Darius Wójcik, The Geography of Finance (Oxford: OUP, 2007) at Chapter 8.

86 Karen Ho, 'Situating Global Capitalisms: A View from Wall Street Investment Banks' (2005) 20 Cultural Anthropology 68.

87 Financial Conduct Authority (2016), above, p. 14.

88 Howard Gospel, Andrew Pendleton and Sigurt Vitols, Financialization, New Investment Funds and Labour (Oxford: OUP 2014) at p. 21. 
systemic risk which this gives rise to, ${ }^{89}$ and in the hope that regulatory efforts to contain systemic risk may be effective. ${ }^{90}$

The structure of collective investment pooling and management, although efficient in saving transaction costs and providing economies of scale, puts investment intermediaries in a powerful position in the management and control of investment capital amassed and accumulated from disparate sources. Given that investment intermediaries are themselves commercial undertakings, with their own business interests, they could easily seek opportunities to exploit their positions of power for self-serving purposes, while regulation in finance and competition are arguably catching up with instead of defining behaviour. One could argue that, on the basis of empirical research showing an aggregate increase in the cost of finance ${ }^{91}$ (even in the years of cheap money and liberalised competition), efficiency and transaction-cost savings may have been eroded by the rents extracted by financial intermediaries, evidencing a form of exploitation.

\section{(c) Professionalisation of Collective Management in Portfolio Management}

Collective investment management is framed as an activity where intermediaries exercise fiduciary power over entrusted money and assets, and therefore due accountability is owed to beneficiary savers. As will be discussed in Section $\mathrm{D}$, private law and public regulation have to an extent addressed the 'agency' problems of such relationships, ${ }^{92}$ but the inequality of power between investment intermediaries and their beneficiaries is an entrenched phenomenon. Such inequality can be reinforced by the perceived professional and epistemic authority of the financial

89 See extensive discussion and literature citations in Chapter 2, Mads Andenas and Iris H-Y Chiu, The Foundations and Future of Financial Regulation: Governance for Responsibility (Oxford: Routledge, 2014).

90 Luigi Zingales, Capitalism for the People: Recapturing the Lost Genius of American Capitalism (New York: Basic Books 2012) on structural reforms. He advocates the return of Glass-Steagall in the banking sector, but some jurisdictions, like the UK, are adopting an approach to ring-fence retail from investment banking activities, see Chapter 12, Mads Andenas and Iris H-Y Chiu (2014), above, on UK structural reforms, the Vickers Report 2011 and the ensuing government White Paper and legislation, the Financial Services (Banking Reform) Act 2013.

91 Bazot, 'Financial Consumption and the Cost of Finance' (2014), above.

92 However other structural consequences are entailed, as Section D will discuss. 
sector and the social trust in such authority. The financial sector holds itself out in epistemic authority, being staffed by extraordinarily talented persons who are remunerated in significant sums, ${ }^{93}$ and frames such authority in a technical language of portfolio and risk management which is relatively inaccessible. ${ }^{94}$ Further, the financial sector frames its power in a language of knowledge which entrenches it as a key player in shaping global policy and law-making. ${ }^{95}$

Zagzebski ${ }^{96}$ expounds on the importance of epistemic authority, as a form of authority that reasonably intelligent and knowledgeable persons would voluntarily succumb to. The expertise of investment intermediaries and asset managers is framed in technical methods in portfolio and risk management and has over the years been supported by the development of quantitative techniques, many of which have received Nobel prize recognition and acclaim. ${ }^{97}$ Technical knowledge, systems of administration that are inaccessible to the outside and the perpetuation of

93 Guido Ferranini and Maria Cristina Ungureanu, 'Economics, Politics, and the International Principles for Sound Compensation Practices: An Analysis of Executive Pay at European Banks' (2011) 64 Vanderbilt Law Review 432; Gordon L Clark, Nigel Thrift and Adam Tickell, 'Performing Finance: The Industry, the Media and Its Image' (2004) 11 Review of International Political Economy 289; Satyajit Das, Extreme Money: Masters of the Universe and the Cult of Risk (London: Financial Times, 2011).

94 Gillian Tett, Fool's Gold: How Unrestrained Greed Corrupted a Dream, Shattered Global Markets and Unleashed a Catastrophe (London: Abacus Books, 2010); Frank Partnoy, Infectious Greed: How Deceit and Risk Corrupted the Financial Markets (London: Profile Books 2003).

95 Emanuel Adler and Steven Bernstein, 'Knowledge in Power: The Epistemic Construction of Global Governance' in Michael Barnett and Raymond Duvall (eds), Power in Global Governance (Oxford: OUP, 2005) at Chapter 13; Geoffrey RD Underhill, 'Theorizing Governance in a Global Financial System' in Peter Mooschlechner, Helene Schuberth and Beat Weber (eds), The Political Economy of Financial Market Regulation (Cheltenham: Edward Elgar 2006), at p. 4; Geoffrey RD Underhill, 'Markets beyond Politics? The State and the Internationalisation of Financial Markets' (1991) 19 European Journal of Political Research 197; Geoffrey Underhill and Xiaoke Zhang, 'Norms, Legitimacy, and Global Financial Governance' (2006) WEF Working Paper No 13 http:// papers.ssrn.com/sol3/papers.cfm?abstract_id=941389.

96 Linda Trinkaus Zagzebski, Epistemic Authority (Oxford: OUP 2012).

97 Such as the portfolio theory and the Black-Scholes theory in options pricing. 
professionalisation of an industry all reinforce epistemic authority, culminating in the description of financial intermediaries as 'masters of the universe'. 98

Further, Haugaard ${ }^{99}$ argues that the exercise of power can be carried out by dominating the formation of knowledge and the systems for disseminating it. The general financialisation of households, the importance of consumer financial literacy, ${ }^{100}$ the rise of shareholder value, the financialisation of the corporate sector, ${ }^{101}$ and the financialisation of national economies and in the EU provide the wider backdrop for the acceptance of epistemic authority in professional investment management and the inevitable commitment of social trust. The exercise of power by financial intermediaries has however been framed in the language of efficiency, such that the power of the financial sector seems neutralised in a democratic marketplace where the invisible hand rules. ${ }^{102}$ The

98 Richard Wachman, 'Reborn Masters of the Universe', The Guardian (London, 19 July 2009); Richard Anderson, 'Masters of the Universe: Meet the World's Best-Paid Men', BBC News (London, 2 February 2011).

99 Mark Haugaard (ed.), Power: A Reader (Manchester: Manchester University Press 2002) at Chapter 15; Mark Haugaard, The Constitution of Power: A Theoretical Analysis of Power, Knowledge and Structure (Manchester: Manchester University Press 1997) at Chapter 9.

100 Underlined by the establishment of the Consumer Financial Education Body (Financial Services and Markets Act 2000, sch 6) and www.moneymadeclear.gov.uk, the FCA's website for improving consumer financial awareness, according to its objective (Financial Services and Markets Act 2000, s 3). See also discussion in Toni Williams, 'Empowerment of Whom and for What? Financial Literacy Education and the New Regulation of Consumer Financial Services' (2009) 29 Law and Policy 226; Ronen Shamir, 'The Age of Responsibilization: On Market-Embedded Morality' (2008) 37 Economy and Society 1.

101 To be discussed shortly.

102 Harford rightly describes financial markets as only impressionistic free markets actually dogged by participants with disparities in information and power. Benchmark and currency manipulation scandals further expose the ugly rigged nature of many financial markets. See Tim Harford, 'Why the efficient markets hypothesis merited a Nobel', Financial Times (14 Oct 2013). On benchmark manipulation, see 'Barclays hit with $£ 290 \mathrm{~m}$ Fine over LIBOR Fixing', The Telegraph (27 June 2012); 'UBS Latest Bank to be Hit with Multimillion LIBOR Fine', The Guardian (13 December 2012); 'RBS Fined $£ 390 \mathrm{~m}$ for Rigging LIBOR Interest Rate', The Guardian (6 February 2013). Martin Wheatley, The Wheatley Review of LIBOR (Sep 2012). On foreign exchange manipulation, see 'Citigroup forex trader fired amid global probe', Financial Times (10 Jan 2014); 'Deutsche Bank braced for fines in forex probes: sources', Reuters (28 May 2014); 'Barclays suspends six foreign exchange traders', Financial Times (1 Nov 2013); 'UBS First to Report FX Rigging Shows 
financial elites have also been crucially important in shaping international financial law and regulatory standards. ${ }^{103}$

Further, the rise of the wealthy and privileged financial elite ${ }^{104}$ has been observed and the typical media representation of the talented and successful banker is an elitist and influential individual, leading a fast-paced and luxurious life. ${ }^{105}$ This depiction of a successful financier has however garnered social distaste since the global financial crisis 2007-09 as the extraction of rents and excessive remuneration by financiers continued while social losses were being borne by ordinary taxpayers.

Law and regulation have, since the global financial crisis of 2007-09, taken a more determined stance towards governing such power. ${ }^{106}$ Regulatory governance now takes the form of increased direct regulatory intervention into financial activities, markets and even internal structures, ${ }^{107}$ as well as the enhancement of client or counterparty accountability. The distrust of finance is a turning point for regulatory reforms post the global financial crisis and the attempt to govern the power of finance has been manifest in many forms of prudential, conduct and

EU Immunity Flaws', Bloomberg (2 Apr 2014); 'Foreign exchange trading faces SFO criminal investigation', The Guardian (21 July 2014).

103 For example, see Geoffrey R D Underhill, 'Theorizing Governance in a Global Financial System' in Peter Mooschlechner, Helene Schuberth and Beat Weber (eds), The Political Economy of Financial Market Regulation (Cheltenham: Edward Elgar 2006), at p. 4; Stefano Pagliari, 'Who Governs Finance? The Shifting Public-Private Divide in the Regulation of Derivatives, Rating Agencies and Hedge Funds' (2012) 18 European Law Journal 44. And cites in Chapter 3, Mads Andenas and Iris H-Y Chiu (2014), above.

104 John Scott, Power: Key Concepts (Cambridge: Citizenry Press, 2001) at pp. 78-79. Dembinski, Finance (2009), above.

105 Gordon L Clark, Nigel Thrift and Adam Tickell, 'Performing Finance: The Industry, the Media and Its Image' (2004) 11 Review of International Political Economy 289.

106 See generally the argument made in Mads Andenas and Iris H-Y Chiu, The Foundations and Future of Financial Regulation (2014), above regarding how policy-makers anchor new and interventionist regulatory measures on the rhetoric of financial stability and macro-prudential regulation.

107 Such as the reforms dealing with central clearing of OTC derivatives contracts, transaction transparency and reporting in the Markets in Financial Instruments Regulation II (2014); the European Markets Infrastructure Regulation (2013), the regulatory framework for credit rating agencies in the EU in the Credit Rating Agencies Regulation (2009, amended 2011, 2013), and the direct regulation of bankers' remuneration in the Capital Requirements Directive IV (2013). 
structural regulations. ${ }^{108}$ The relevant aspects of law and regulation in governing intermediary power will be discussed in greater detail in the chapters dealing with specific investment fund entities in order to assess their impact on changes in behaviour.

\section{(d) Making the Realisation of Investment Returns a Business and Profit-Oriented Activity}

Making investment capital productive and yielding a return is essentially an enterprise, a business. Investment intermediation is less a service for social needs than a business susceptible to performance targets. Although good performance would ultimately benefit the beneficiaries who have entrusted investment capital in the first place, it is primarily a business objective to be met by the intermediaries who seek success for the business of investment management as such. Such business success need not be aligned with the expectation of social 'success' in the form of adequate provision for savers' social needs, as investment management is a partially intermediated activity that does not in principle shield investors from the vicissitudes of their investment decisions. This is a relatively disturbing disconnect that the financialised masses have come to accept, largely because of the 'ordinarisation of risk' which will be discussed shortly.

Investment returns are increasingly being generated through trading and making market gains instead of through real productivity. ${ }^{109}$ Generating relative or absolute returns (depending on the investment mandate) has become the enterprise objective of collective investment management entities. However, generating a return on financial assets through trading is a fundamentally zero-sum game. In a marketplace, one's decision to buy or sell an asset can only be realised if the counter-party holds a completely contrary view as to the potential returns on the asset. Harford ${ }^{110}$ rightly points out that the efficient marketplace is an illusion and financial sector participants engage in arbitrage and zero-sum game

108 Mads Andenas and Iris H-Y Chiu, The Foundations and Future of Financial Regulation (Oxford: Routledge, 2014) generally.

109 Howard Gospel, Andrew Pendleton and Sigurt Vitols, Financialization, New Investment Funds and Labour (Oxford: OUP 2014); Kay explains that the rise in trading, i.e. the reliance on marketplaces to generate profit, has replaced relational investments, especially in banking, see John Kay, Other People's Money (London: Profile Books 2015) at pp. 16ff.

110 Tim Harford, 'Why the efficient markets hypothesis merited a Nobel', Financial Times (14 Oct 2013). 
transactions $^{111}$ in order to maximise their respective profits. In which case financialised solutions to meet social needs cannot universally meet all demands and it is inevitable that a portion of social needs will fail to be met. ${ }^{112}$ Legal and regulatory frameworks in relation to accountability do not micro-manage or guarantee investment performance. Hence, beneficiaries would have no certainty that their social needs in saving through investment would be met while nevertheless having to pay for the privilege of having accessed the financialised methodologies and processes of investment to meet those needs. The disconnect between the social nature of saving and the enterprise nature of investment is a perennial concern that has yet to be addressed.

In keeping with the enterprise and commercial nature of investment services as a business activity, investment intermediaries engage in profit-seeking. Profit-seeking behaviour underlies a number of practices which may be fundamentally contrary to the social nature of saving needs. For example, the imposition of opaque fee and cost structures by funds is a pervasive phenomenon that may affect the ultimate saving outcomes for beneficiaries. ${ }^{113}$

The enterprise nature of investment management as a business also supports developments in innovative strategies in risk-taking that may obfuscate the nature of risk by employing the language of opportunity. ${ }^{114}$ The rise in financial innovation such as derivatives for risk management

111 Roger Bootle, The Trouble with Markets: Saving Capitalism from Itself (London: Nicholas Brealey Publishing, 2009, 2012).

112 The zero-sum game nature of much of financial activity that is not creative wealth creation but distributive only in nature is noted in Mukunda, 'The Price of Wall Street's Power' (2014), above.

113 Critique in John C Bogle, Common Sense on Mutual Funds (Chichester: John Wiley \& Sons, 2011). However, it may be argued that whether fees are deserved or otherwise, especially in active management as will be discussed in Chapters 2 and 3, remains highly arguable. See 'We Do Not Need 80\% Active Management', Financial Times (11 May 2014), quoting a report by the UK's Department for Communities and Local Government. This debate has been played out in CalPERS' decision to drop hedge funds in 2014, which is not supported by many others, including UK pension funds. See 'CalPERS Ditches Hedge Funds', Financial Times (16 Sep 2014) and 'UK's £1trn Corporate Pensions Sector Stands by Hedge Funds', Financial Times (17 Sep 2014) but the London Pension Funds Authority nevertheless criticised hedge fund fees for being exorbitant, 'UK Pension Fund Criticises Hedge Fund Fees', Financial Times (16 Sep 2014).

114 Paddy Ireland, 'The Financialization of Corporate Governance' (2009) at http://ssrn.com/abstract=2068478; Paul H Dembinski, Finance: Servant or Deceiver (2009), above. 
has given rise to speculative gambling ${ }^{115}$ with such instruments in order to generate gains, having the effect of augmenting and multiplying gains and losses in the market using 'other people's money'. The global financial crisis of 2007-09 revealed how the use of derivatives could result in phenomenal losses for institutions on the wrong side of the bet. Zero-sum games in financial markets entail unpredictable distributions of risks and losses, subjecting savers' social needs to the volatility of finance and investment as businesses - as manifested in the need for the public bailout of banks in the global financial crisis. ${ }^{116}$ Should finance operate as businesses, a question raised by Arup? ${ }^{117}$ It is important to appreciate the impact of profit-seeking and competitive pressures upon the financial sector and how such may distort incentives away from meeting the underlying social needs of savers.

The profit-seeking nature of the investment management enterprise has the following ramifications. The immediate gratification of seeking short-term yield may result in short-termist and sub-optimal investment decisions and behaviour. Short-termist decisions may over-emphasise liquidity and the lack of commitment to investment, ${ }^{118}$ chasing fleeting gains deriving from fluctuating market sentiment but disengaged from real productivity, a point that will be taken up again shortly. Sub-optimal decisions may be in the nature of behavioural herding ${ }^{119}$ as the perceptions of winning strategies converge ${ }^{120}$ upon a few perceived winning practices. Further, sub-optimal decisions may be taken in respect of risk-taking, such as where leverage is employed, raising the question of

115 Emilios Avgouleas, 'Regulating Financial Innovation: A Multifaceted Challenge to Financial Stability, Consumer Protection, and Growth' in The Oxford Handbook of Financial Regulation (forthcoming 2014).

116 Michael Hudson, Finance Capitalism and its Discontents (Dresden: Islet Verlag, 2012).

117 C Arup, 'The Global Financial Crisis: Learning from Regulatory and Governance Studies' (2010) 32 Law and Policy 363.

118 Eckhard Hein, The Macro-economics of Finance Dominated Capitalism and its Crisis (Cheltenham: Edward Elgar 2012) at Chapter 3.

119 Emilios Avgouleas, 'The Global Financial Crisis, Behavioural Finance and Financial Regulation: In Search of a New Orthodoxy' (2009) 9 Journal of Corporate Law Studies 23.

120 Such as closet index hugging, John Authers, 'Active fund managers are closet index huggers', Financial Times (London, 12 March 2014); smart beta, see John Authers, 'Is Smart beta smart enough to last?', Financial Times (London, 11 June 2014). Even hedge fund strategies that are more flexible and varied may be categorised into a number of dominant themes, see F S L'Habitant, Hedge Funds: Myths and Limits (Chichester: Wiley Finance 2002). 
whether risks should be so augmented even if profitability may be heightened. ${ }^{121}$ Further, as long as short-term yield on investments is achieved, and the business objectives of investment management attained, little attention would be paid to fundamental issues such as whether asset prices may be sustained, ${ }^{122}$ whether speculative finance may cause any social damage or harm ${ }^{123}$ or whether the disengagement from real productivity increases is a disturbing phenomenon. ${ }^{124}$ The spirit of capital formation through pooled collective saving from the masses would be lost in the more myopic business orientation of investment management as an enterprise. It may further be argued that such a business orientation of investment management is supported to an extent by law and regulatory frameworks, leaving the sustainability of investment management practices on the back-burner. The issues of sustainability of business models in investment management and disengagement from the real social needs of beneficiaries are being augmented on a global scale as finance continues to relentlessly expand itself into a global business. ${ }^{125}$ Section D will further discuss the part played by law and regulation in reinforcing such short termism.

Turning an activity into a business or enterprise does not need to be an exploitative foray that foists negative externalities onto others. Adam Smith's original vision of enterprise is based on productive wealth creation, fair and efficient trading and regulating against exploitation. ${ }^{126}$ It may be argued that it is the rise of contemporary shareholder value-based profit maximisation that has caused business vision to become increasingly tunnelled. The rise in the shareholder value ideology

121 Margaret M Blair, 'Making Money: Leverage and Private Sector Money Creation' (2012) 36 Seattle University Law Review 417.

122 Roche and McKee, New Monetarism (2007), above.

123 Emilios Avgouleas, 'Regulating Financial Innovation: A Multifaceted Challenge to Financial Stability, Consumer Protection, and Growth' in The Oxford Handbook of Financial Regulation (forthcoming 2014).

124 Costas Lapavitsas, 'Financial Capitalism: Crisis and Financial Expropriation' in Costas Lapavitsas ed., Financialization in Crisis (Leiden: Brill Publishers, 2012) at p. 15; James Crotty, 'The Neoliberal Paradox: The Impact of Destructive Product Market Competition and 'Modern' Financial Markets on Nonfinancial Corporation Performance in the Neoliberal Era' in Gerald A Epstein ed., Financialization and the World Economy (Cheltenham: Edward Elgar, 2005) at p. 77.

125 Karen Ho, 'Situating Global Capitalisms: A View from Wall Street Investment Banks’ (2005) 20 Cultural Anthropology 68.

126 Spencer J Pack, Capitalism as a Moral System (Cheltenham: Edward Elgar 1991, 2010) at Chapters 2 and 3. 
has fundamentally changed business behaviour, causing businesses to focus on short-term calculable value generation at the expense of long-term wealth creation. ${ }^{127}$ However the shareholder value ideology is deeply rooted in finance economists' view of the private nature of the corporation ${ }^{128}$ and as this book will argue later, is fervently supported by the investment management community in their corporate governance roles. This book will argue that the investment management community's support for the shareholder value ideology is ultimately related to its business objectives in the enterprise of investment management.

The business nature of investment management continues to evolve as investment fund entities and asset managers pick up new opportunities in the post-global financial crisis markets that banks hesitate to tread due to a new raft of regulatory constraints. The growth of shadow banking in the investment management industry, ${ }^{129}$ taking on more and expanded maturity transformation functions raises questions as to new risks such activities bring to beneficiaries, society and the global citizenry. Further, socio-analyses of the global financial crisis warn of financial activity becoming an end in itself, and the ethos of service in intermediation becomes lost in the empire-building of an ever-expanding scope of intermediary activities. ${ }^{130}$

127 Paddy Ireland (2009), above; Engelbert Stockhammer, 'Financialization and the Slowdown of Accumulation' in Ismail Erturk, Julie Froud, Sukhdev Johal, Adam Leaver and Karel Williams (eds), Financialization At Work: Key Tests and Commentary (Oxford: Routledge, 2008); James Crotty, 'The Neoliberal Paradox: The Impact of Destructive Product Market Competition and 'Modern' Financial Markets on Nonfinancial Corporation Performance in the Neoliberal Era' in Gerald A Epstein ed., Financialization and the World Economy (Cheltenham: Edward Elgar, 2005) at p. 77; Chapter 4, Eckhard Hein, The Macroeconomics of Finance Dominated Capitalism and its Crisis (Cheltenham: Edward Elgar 2012).

128 Sanford J Grossman and Oliver D. Hart, 'The Costs and Benefits of Ownership: A Theory of Vertical and Lateral Integration' (1986) 94 Journal of Political Economy 691; Frank H Easterbrook and Daniel R Fischel, The Economic Structure of Corporate Law (Mass: Harvard University Press, 1991), but see Lynn Stout, The Shareholder Value Myth: How Putting Shareholders First Harms Investors, Corporations, and the Public (Berrett-Koehler, 2012).

129 'The Lure of Shadow Banking', The Economist (10 May 2014) provides an extended discussion of the pros and cons of the rise of shadow banking; Financial Stability Board, Global Shadow Banking Monitoring Report 2013 and 2012.

130 Peter Pelzer, 'Risk as Present Futures: An Elaboration on Risk and Fear' in Susan Long and Burkard Sievers (eds), Towards a Socioanalysis of Money, Finance and Capitalism (Oxford: Routledge, 2013) at p. 149; Ian S Miller, 


\section{(e) Commoditisation of Investible Subject Matter as Asset Classes and (f) Detachment of Investment Returns from Real Activity}

Financialisation has increasingly conditioned our perceptions in terms of what could be marketised, and we have become used to accepting a wide range of subject matter that can be assetised, commodified and traded. ${ }^{131}$ As trading becomes a mainstay of generating income from investment, the commodification of various assets into tradeable subject matter is on the rise. ${ }^{132}$ Many commentators have opined that investment gains are not generated by putting capital to work in generating real productivity gains - in particular, in support of companies with a distinctive business purpose - but are made in the relatively easier manner of value arbitrage in trading assets. ${ }^{133}$ As Walter and Sisli $^{134}$ argue, this is not entirely a perspective that is created by the fund industry itself - beneficiaries would also like to enjoy the benefits of yield, liquidity and safety, to have their cake and eat it. Investment intermediaries armed with a glut of supply in capital are in search of tradeable assets that could meet those needs. A key asset class is publicly traded corporate equity, but asset classes $^{135}$ include private corporate equity, foreign corporate equity, real

'Profit as Organising Meaning' in Susan Long and Burkard Sievers (eds), Towards a Socioanalysis of Money, Finance and Capitalism (Oxford: Routledge, 2013) at p. 306; Seth Allcorn and Howard F Stein, 'What, Me Worry? Deregulation and its Discontents: Accurate Reality Testing Reveals Flaws to Deregulation' in Susan Long and Burkard Sievers (eds), Towards a Socioanalysis of Money, Finance and Capitalism (Oxford: Routledge, 2013) at p. 120.

131 Ho, 'Situating Global Capitalisms' (2005), above; Jonathan Nitzan and Shimshon Bichler, Capital as Power: A Study of Order and Creorder (Oxford: Routledge, 2009).

132 Howard Gospel, Andrew Pendleton and Sigurt Vitols, Financialization, New Investment Funds and Labour (Oxford: OUP 2014) at p. 19.

133 Branka Mraović, 'A Free Market Capitalism or a Speculative Market Capitalism?' (2011) 7 Social Responsibility Journal 578; Stephan Schulmeister, 'On the Manic-Depressive Fluctuation of Speculative Prices' in Eckhard Hein, Torsten Niechoj, Peter Spahn and Achim Truger (eds), Finance-led Capitalism: Macro-economic Effects of Changes in the Financial Sector (Marburg: Metropolis Verlag 2009) at p. 309; Roger Bootle, The Trouble with Markets: Saving Capitalism from Itself (London: Nicholas Brealey Publishing, 2009, 2012).

134 Walter and Sisli, 'The Asset Management Industry' (2007), above.

135 The UK Financial Services and Markets Act 2000 section 235 defines property that can be collectively managed as capable of being of any description, this is widely interpreted in case law, see Financial Services Authority v Fradley [2005] EWCA Civ 1183 CA. 
estate, infrastructure, commodities, precious metals, art, wine, antiques, cars, and synthetic 'assets'.

The focus on market gains gives rise to a few ramifications. First, wealth is generated as rentier income, ${ }^{136}$ and such a form of wealth generation results in the gradual under-valuation of labour and the diminished capacity of labour to generate wealth through productivity, causing income inequalities between asset-owning classes and those without. ${ }^{137}$ Second, the pursuit of market gains can result in driving up the value of asset prices without any connection to the fundamentals of the wealth generating capacity of the assets in question. ${ }^{138}$ Asset price bubbles are not further helped in many decades of loose monetary policy ${ }^{139}$ which has allowed cheap money to chase asset prices. The desire to manage such volatility results in financial innovation devised to hedge and manage unexpected downturns in asset prices so as to minimise losses. Financial innovation in derivatives has exploded but managing the unknown or unknowable risks ${ }^{140}$ remains a challenging pursuit. ${ }^{141}$ The desire to capture market profits has been so great that sub-optimal or not-yet-ready risk management models have been put to

136 R H Tawney, 'The Rentier and Financier', John Maynard Keynes, 'Speculation, Cyclicality and the Euthanasia of the Rentier' and Greta Krippner, 'Accumulation and the Profits of Finance' in Ismail Erturk, Julie Froud, Sukhdev Johal, Adam Leaver and Karel Williams (eds), Financialization At Work: Key Tests and Commentary (Oxford: Routledge, 2008); Gerald Epstein and Arjun Jayadev, 'The Rise of Rentier Incomes in OECD Countries: Financialization, Central Bank Policy and Labor Solidarity' in Gerald A Epstein ed., Financialization and the World Economy (Cheltenham: Edward Elgar, 2005) at p. 46.

137 Ken-Hou Lin and Donald Tomaskovic-Devey, 'Financialization and U.S. Income Inequality, 1970-2008' (2013) 118 American Journal of Sociology 1284; Eckhard Hein, 'Finance-dominated Capitalism and Redistribution of Income: A Kaleckian Perspective' (2013) at http://ssrn.com/abstract=2198919; Basak Kus, 'Financialisation and Income Inequality in OECD Nations: 1995-2007' (2012) 43 The Economic and Social Review 477; Gerard Dumenil and Dominique Levy, 'Financialization, Neo-liberalism and Income Inequality in the USA' in Ismail Erturk, Julie Froud, Sukhdev Johal, Adam Leaver and Karel Williams (eds), Financialization At Work: Key Tests and Commentary (Oxford: Routledge, 2008). 138 Michael Hudson, Finance Capitalism and its Discontents (Dresden: Islet Verlag, 2012), at pp. 5, 19, 23.

139 Roche and McKee, New Monetarism (2007), above.

140 F X Diebold, N Doherty and R J Herring (eds), The Known, The Unknown and The Unknowable in Financial Risk Management (Princeton University Press, 2010).

141 Douglas Hubbard, The Failure of Risk Management: Why It's Broken and How Do We Fix it? (Chichester: John Wiley \& Sons, 2009). 
use and overly-relied upon. ${ }^{142}$ The story of the global financial crisis is essentially a story of increased securitisation of exotic assets, sub-optimal risk management and asset price bust. ${ }^{143}$

Further, Hudson ${ }^{144}$ argues that the dangerous securitisation of various debts such as sovereign, personal, distressed debt etc are pursuant to the desire of extracting value even when such extraction of value results in damaging expropriation of social wealth. Hence, the business of investment management by trading in exotic and questionable assets could be on the whole socially adverse. The assetisation of subject matter for market gains could also distort their nature such that their long-term wealth creating potential may be jeopardised by market pressures.

Publicly traded corporate equity is a case in point. Markets tend to evaluate asset values based disproportionately on short-term earnings prospects, resulting in the phenomenon that investment in publicly traded corporate equity is less and less related to the fundamental value creation undertaken by companies in producing goods and services, ${ }^{145}$ but more related to market demands and sentiment. Economic theories such as the Efficient Capital Markets Hypothesis ${ }^{146}$ posit that the value of corporate equity at any given time reflects all the information relating to the corporation and that must include its value creation characteristics and potential. However, many behavioural economists ${ }^{147}$ have shown that the trading prices of corporate equity are often based on market sentiment

142 Riccardo Rebonato, Plight of the Fortune Tellers: Why we Need to Manage Financial Risk Differently (NJ: Princeton University Press, 2007).

143 Richard E Mendales, 'Collateralized Explosive Devices: Why Securities Regulation Failed to Prevent the CDO Meltdown, and How to Fix it' [2009] University of Illinois Law Review 1359.

144 Michael Hudson, 'From Marx to Goldman Sachs: The Fictions of Fictitious Capital, and the Financialization of Industry' (2010) 38 Journal of Socialist Theory 419.

145 Charles J Whelan, 'Money Manager Capitalism: Still Here but Not Quite as Expected' (2002) 36 Journal of Economic Issues 401; John Hendry, Paul Sanderson, Richard Barker and John D Roberts, 'Owners or Traders? Conceptualizations of Institutional Investors and Their Relationship with Corporate Managers' (2006) 59 Human Relations 1101.

146 Eugene Fama, 'Efficient Capital Markets: A Review of Theory and Empirical Work'(1970) 25 Journal of Finance 383.

147 D Langevoort, 'Taming the Animal Spirits of the Stock Markets: A Behavioral Approach to Securities Regulation' (2002) 97 Northwestern University Law Rev 135; Thomas Gilovich, Dale Griffin and Daniel Kahneman (eds), Heuristics and Biases: The Psychology of Intuitive Judgment (Cambridge: Cambridge University Press 2002); Daniel Kahneman and Amos Tversky (eds), Choices, Values and Frames (Cambridge: Cambridge University Press 2003); 
and irrational perceptions and valuations, raising the question of disconnect with the fundamentals of businesses that are publicly traded. The treatment of publicly traded corporate equity as liquid market assets has also resulted in excessive commodification of publicly traded companies - as entities that are easily bought or sold for a profit, and as entities out of which value can be extracted for a profit.

Financialisation has fundamentally changed the role of the corporate sector from long-term creators of wealth in real production to a 'loose collection of assets' that could be manipulated, combined and disassembled for the purposes of commodification and generation of value for investors, managers and financial intermediaries. ${ }^{148}$ Little thought is given to the distinctive business purpose of each business entity; each entity is viewed purely in terms of its short-term financial characteristics. Further, the rise in the shareholder value ideology has narrowed down the value of the corporation to the value reflected in the price of tradeable corporate equity. The rise in the shareholder value ideology has fundamentally changed management behaviour, causing management to focus on short-term calculable value generation at the expense of investment in long-term productivity enhancements and wealth creation. ${ }^{149}$ Such behaviour is compelled by the nature of short-termist investment that lacks commitment and patience. ${ }^{150}$ Corporate decisions made on the basis of

Robert H Shiller, 'Bubbles, Human Judgment, and Expert Opinion' (2002) 58 Financial Analysts Journal 18; Irrational Exuberance (Crown Business, 2006).

148 Paul H Dembinski, Finance: Servant or Deceiver (trans. by Kevin Cook, Basingstoke: Palgrave Macmillan 2009); Ken-Hou Lin and Donald TomaskovicDevey, 'Financialization and U.S. Income Inequality, 1970-2008' (2013) 118 American Journal of Sociology 1284. Also see John Kay, Other People's Money (2015), above at pp. 45ff.

149 Paddy Ireland, 'The Financialization of Corporate Governance' (2009), above; Engelbert Stockhammer, 'Financialization and the Slowdown of Accumulation' in Ismail Erturk, Julie Froud, Sukhdev Johal, Adam Leaver and Karel Williams (eds), Financialization At Work: Key Tests and Commentary (Oxford: Routledge, 2008); James Crotty, 'The Neoliberal Paradox: The Impact of Destructive Product Market Competition and 'Modern' Financial Markets on Nonfinancial Corporation Performance in the Neoliberal Era' in Gerald A Epstein ed., Financialization and the World Economy (Cheltenham: Edward Elgar, 2005) at p. 77.

150 Gordon L Clark and Darius Wójcik, The Geography of Finance (Oxford: OUP, 2007) at p. 11 describes the deus ex machine of their book as financial institutions whose commitment to corporate executives is conditional and subject to competing market-based investment opportunities. 
short-termist value generation include shrinking the asset base of companies to boost returns on net assets, ${ }^{151}$ shrinking the capital base of companies by buying back shares or distributing dividends so that shortterm returns on equity could be boosted while compromising longer term research and development expenditure. ${ }^{152}$ The release of capital into the marketplace does not result in deployment in real productivity but provides a basis for more rentier income to be earned, such as financing leverage. ${ }^{153}$ Financialisation also affects companies in terms of their strategic behaviour - many companies increasingly seek sources of income from investment or developing financial products instead of developing innovations in product or productivity. ${ }^{154}$ Such strategic changes in business are further reinforced by remuneration structures for management being aligned with performance defined according to shareholder value. ${ }^{155}$ The partnership between business and finance has flourished in the financialisation era and has boosted the power of financial intermediaries who design and execute numerous financialised transactions for corporations. The financialisation of the corporate sector has however resulted in the stagnation of wealth creation in the corporate

151 Mukunda, 'The Price of Wall Street's Power' (2014), above; William Lazonick and Mary O'Sullivan, 'Shareholder Value and Corporate Governance' both in Ismail Erturk, Julie Froud, Sukhdev Johal, Adam Leaver and Karel Williams (eds), Financialization At Work: Key Tests and Commentary (Oxford: Routledge, 2008).

152 Eckhard Hein, 'Finance-dominated Capitalism and Redistribution of Income: A Kaleckian Perspective' (2013) at http://ssrn.com/abstract=2198919; Julie Froud, Sukhdev Johal, Adam Leaver and Karel Williams, Financialization and Strategy: Narrative and Numbers (Oxford: Routledge 2006) at Chapter 4; William Lazonick and Mary O'Sullivan, 'Shareholder Value and Corporate Governance' in Ismail Erturk, Julie Froud, Sukhdev Johal, Adam Leaver and Karel Williams (eds), Financialization At Work: Key Tests and Commentary (Oxford: Routledge, 2008).

153 Michael Hudson, Finance Capitalism and its Discontents (Dresden: Islet Verlag, 2012) at p. 222.

154 Greta Krippner, 'Accumulation and the Profits of Finance' in Ismail Erturk, Julie Froud, Sukhdev Johal, Adam Leaver and Karel Williams (eds), Financialization At Work: Key Tests and Commentary (Oxford: Routledge, 2008); Julie Froud, Sukhdev Johal, Adam Leaver and Karel Williams, 'GE under Jack Welch: Narrative, Performative and the Business Model' in Ismail Erturk, Julie Froud, Sukhdev Johal, Adam Leaver and Karel Williams (eds), Financialization At Work: Key Tests and Commentary (Oxford: Routledge, 2008).

155 Andrew Smithers, The Road to Recovery: How and Why Economic Policy must Change (Chichester: John Wiley \& Sons, 2013). 
sector over the long term. ${ }^{156}$ Folkman and others argue that financial intermediaries generate a lot of short-termist corporate restructuring and finance work in order to extract rents rather than to help companies achieve long-term growth and value. ${ }^{157}$ Santoro and Strauss also argue that the profit generation by financial intermediaries has become a form of 'profit disjunction' as profits could be generated through complex innovations whether or not the transactions generating such profits are of real utility for productive purposes. ${ }^{158}$

Finally, Martin ${ }^{159}$ describes financialisation as bringing about an atomised perception of property - which is a value-driven desire that seeks to combine, disperse and calculate how the proprietary nature of assets can be used to generate value. This results in a calculative mindset that encourages selfish exploitation of assets for extraction of value. The changes to financial, corporate and social culture are enduring and disturbing.

The business model of modern investment management overall leads to an over-reliance on market realisation of profits and a general hampering of putting assets to productive good use, including corporations which are both wealth-generating organisations and marketised tradeable assets in themselves. The reliance on fickle asset prices to generate income and making the real economy a less attractive arena for wealth creation are both unsustainable phenomena. Financialisation increasingly correlates with falling rates of real productivity, ${ }^{160}$ such as in developed countries where financialisation has become more and more entrenched. Policy and

156 Carlos Morera Camacho and Jose Antonio Rojas Nieto, 'The Globalisation of Finance Capital 1997-2008' in Costas Lapavitsas ed., Financialization in Crisis (Leiden: Brill Publishers, 2012) at 161; Eckhard Hein, 'Rising Shareholder Power: Effects on Distribution, Capacity Utilisation and Capital Accumulation in Kaleckian and Post-Kaleckian Models' in Eckhard Hein, Torsten Niechoj, Peter Spahn and Achim Truger (eds), Finance-led Capitalism: Macroeconomic Effects of Changes in the Financial Sector (Marburg: Metropolis Verlag 2009) at 89.

157 Peter Folkman and others, 'Working for Themselves: Financial Intermediaries and Present Day Capitalism' (2007) 49 Business History 552.

158 Michael A Santoro and Ronald J Strauss, Wall Street Values: Business Ethics and the Global Financial Crisis (Cambridge: Cambridge University Press, 2012), Chapter 2.

159 Randy Martin 'The Twin Towers of Financialization: Entanglements of Political and Cultural Economies' (2009) 3 The Global South 108.

160 Jacob Assa, 'Financialization and its Consequences: The OECD Experience' (2012) 1 Finance Research 35; Thomas I Palley, Financialisation: The Economics of Finance Capital Domination (Basingstoke: Palgrave Macmillan 
law have not questioned ${ }^{161}$ how investment management generates its returns, although there is cognisance that investment management is increasingly disconnected with its starting social purposes. ${ }^{162}$ It is perhaps timely to make a statement regarding the undesirability of excessive reliance on market gains. It is arguable that investment for value arbitrage is not the same as putting capital to work. Market trading should primarily focus on the needs for liquidity so that it is not overly relied upon as an income generator.

\section{(g) The Widespread Acceptance of Financial Risk-bearing by Individual Citizens}

The financial sector appeals to many to participate in financial services and markets as the primary means to meet their needs, but the sector nevertheless is able to evade lofty promises by framing financial participation as a form of liberalised decision-making, autonomy, self-care and individual responsibility. ${ }^{163}$ Financialisation thus achieves an effect of convincing users of financial services and markets that they bear the ultimate risk of exposure in the markets.

Financial participation for the many is framed as a form of democratised exposure to market risk. The turning of savings into investment results in the perception that exposure to market risk has become a way of life. The market is framed as a neutral arena, spontaneous order, ${ }^{164}$ the 'invisible hand' not subject to the control of particular power, ${ }^{165}$ further engendering acceptance of its verdict. For example, the shift from

2013); Eckhard Hein, The Macro-economics of Finance Dominated Capitalism and its Crisis (Cheltenham: Edward Elgar 2012) at Chapter 4.

161 Law Commission, Fiduciary Duties of Investment Intermediaries (July 2014) at http://lawcommission.justice.gov.uk/areas/fiduciary_duties.htm concluding that there is no need to change the law relating to investment intermediaries' relationships with beneficiaries in order to make equity markets work better for meeting saver needs.

162 BIS, Kay Review (2012), above.

163 Paul Langley, 'Uncertain Subjects of Anglo-American Financialization' (2007) 65 Cultural Critique 67.

164 The Hayekian view, see F A Hayek, Individualism and Economic Order (University of Chicago Press, 1944); The Constitution of Liberty (University of Chicago Press, 1960).

165 Which remains an important cornerstone in understanding economic organisation of life, see Peter J Boettke, 'Teaching Economics, Appreciating Spontaneous Order, and Economics as a Public Science' (2010) at http:// papers.ssrn.com/sol3/papers.cfm?abstract_id=1661513. 
defined benefit to defined contribution pension schemes in many occupational pension funds across OECD countries in the last decade or so would result in increased exposure of households to market risk. ${ }^{166}$ Law and regulation have also played a significant role in maintaining the perceived neutrality, objectivity and fairness of the market as an essential infrastructure. ${ }^{167}$ However, Broadbent et al, in studying the effect of shifting from defined benefit pension plans to defined contribution ones, report that the acceptance of exposure to market risk does not mean that households understand what the risks mean or how to manage them. It is curious that this disconnect is accepted and hardly questioned. ${ }^{168}$ Pike and Pollard ${ }^{169}$ report on the extent and pervasiveness of financial risk across geographies, and it seems that the phenomenon of widespread social acceptance of financial risk-bearing has become universal.

It is arguable that households are sold the responsibility of bearing their ultimate financial risks as the language of empowerment and autonomy that surrounds participation in financial markets glibly convinces the retail constituent of such responsibility. Erturk at al ${ }^{170}$ argue that retail constituents could be sold financial services or products they do not really understand and yet come away with the impression that the decision to purchase was an act of responsible self-management. O'Horrigan ${ }^{171}$ argues that 'New Finance' championing individual choice and responsibility obscures the fact that individual choice is being exploited by intermediaries who seek to serve their own gains and meet

166 John Broadbent, Michael Palumbo and Elizabeth Woodman, 'The Shift from Defined Benefit to Defined Contribution Pension Plans - Implications for Asset Allocation and Risk Management' (BIS Working Paper 2006) at http:// www.bis.org/publ/wgpapers/cgfs27broadbent3.pdf.

167 Such as regulation on market conduct and against market abuse, e.g. EU Market Abuse Regulation 2014, the regulation of price discovery and transparency on markets, The MiFID II recast Directive 2014; the Transparency Directive 2004 amended as of 2014.

168 Simone Polillo, 'Wildcats in Banking Fields: The Politics of Financial Inclusion' (2011) 40 Theor Soc 347 argues that the democratisation of exposure to market risk is a façade used to lure the masses into financial participation to generate fees and income for the financial sector and little consideration is given to the needs of participants.

169 Andy Pike and Jane Pollard, 'Economic Geographies of Financialization' (2010) 86 Economic Geography 29.

170 Ismail Erturk, Julie Froud, Sukhdev Johal, Adam Leaver and Karel Williams, 'The Democratization of Finance? Promises, Outcomes and Conditions' (2007) 14 Review of International Political Economy 553.

171 James O'Horrigan, 'The Ethics of the New Finance' (1987) 6 Journal of Business Ethics 97. 
their sales volume targets. Financialisation is underpinned by a form of new ethics that encourages an every man for himself attitude, and myopic self-serving behaviour on the part of intermediaries. In this way, a rhetoric of personal responsibility obscures the unfairness in the uneven distribution of risk or risk management between financial intermediaries and ultimate users. Commentators ${ }^{172}$ discuss the prevalent uneven distribution of risk between end-users who are persuaded to participate in finance and the opportunistic profit-making carried out by the financial sector.

However, the idea of encouraging individuals into financial assets has been very much supported by law. For example, disclosure-based regulation surrounding investment is premised on giving choice and responsibility to the investor to make an informed decision. The emphasis placed on financial literacy by policy-makers is also in the vein of supporting the risk-bearing by individuals as a way of life. However, consumer financial literacy education may be limited in helping consumers overcome inherent bounded rationality. ${ }^{173}$ Williams ${ }^{174}$ and Willis ${ }^{175}$ argue fervently against regarding consumer financial literacy education as sufficient to make consumers entirely responsible for weak financial decisions, shielding regulators and the industry from liability or responsibility. The post global financial crisis reforms have however recognised the political unpopularity and systemic risk effects of social absorption of financial risk and losses, and so more paternalism has been rolled out in consumer protection in the US, EU and UK. ${ }^{176}$

Although the balance of financial risk-bearing may be slightly shifted in consumers' favour in the wake of the post-global financial crisis law reforms, exposure to market risk remains a mainstay in the context of

172 Paul H Dembinski, Finance: Servant or Deceiver (2009), above; Thomas I Palley, 'Financialisation: What it is and Why it Matters' in Eckhard Hein, Torsten Niechoj, Peter Spahn and Achim Truger (eds), Finance-led Capitalism: Macro-economic Effects of Changes in the Financial Sector (Marburg: Metropolis Verlag 2009) at p. 29.

173 Geraint Howells, 'The Potential and Limits of Consumer Empowerment by Information' (2005) 32 Journal of Law and Society 349.

174 Toni Williams, 'Empowerment of Whom and for What? Financial Literacy Education and the New Regulation of Consumer Financial Services' (2007) 29 Law and Policy 226.

175 Lauren E Willis, ‘Against Financial Literacy Education' (2008-9) 94 Iowa Law Review 197.

176 Chapter 8, Mads Andenas and Iris H-Y Chiu, The Foundations and Future of Financial Regulation: Governance for Responsibility (Oxford: Routledge, 2014). 
financialisation. Ultimately savers may still have to face disappointment in unmet savings needs, and these are attributed to the vicissitudes of the market. ${ }^{177}$ In other words, financialisation has revolutionised how needs are met, how resources are to be allocated and used and how economies are run, yet Martin argues that it is essentially a technique, a method that is sold on the ideologies of liberalism and individualism, not promising any particular outcomes to those whose hopes may be entirely placed in it. Kay ${ }^{178}$ also opines that investment management is a matter of 'search and stewardship' for the entrusted savings of savers, but very little intermediation activity is associated with search and stewardship, being concentrated on profit generation through transactionalisation and trading, contributing no real value added to the real economy.

Having sketched the seven 'financialisation norms' that underpin modern collective investment management, we suggest that the 'financialisation' norms, whether or not driven by ideology, business and politics, are at least very much reinforced by law and regulation. The next Section argues that the characteristics of commoditisation, transactionalisation and short-termism in investment management can at least be attributed in part to law and regulation, However, the effects of financialisation and supporting law and regulatory frameworks are greatly supported by the investment management industry as they also underpin the industry's profitability.

\section{LEGAL AND REGULATORY LEGITIMATION OF FINANCIALISATION}

Investment management has always been underpinned by private law in the UK, in contract, trust and fiduciary law. The role of law is essential to such private transactions in terms of determining the terms of transactional bargains and how they will be enforced. However, as the social scale of collective investment management in the financialised era has greatly accelerated, regulation has been introduced to supplement private law. We argue that although regulation has been introduced in the name of investor protection, it achieves an entrenchment of financialisation in the socio-economy, and produces certain unintended consequences in the

177 Pointed out by Luis A Aguilar, US SEC Commissioner, 1 July 2014, reported in http://blogs.law.harvard.edu/corpgov/2014/07/01/evaluating-pensionfund-investments-through-the-lens-of-good-corporate-governance/.

178 John Kay, Other People's Money (2015), above at Chapter 7. 
nature of investment management. The more detailed aspects of regulatory law and their consequences for the practice of investment management are fleshed out in Chapter 2, and this chapter paints the broad themes of how law and regulation have supported the needs and trends in financialised collective investment management, as a key means of understanding how investment funds are incentivised and governed.

The private law of contract or trusts in the UK generally constitutes the investment management mandate, which could include the objectives of investment management, accountability frequencies and requirements, the terms of maturity, payouts and redemptions (where applicable). Further, the relationship of investment management involves entrustment of assets, and this attracts the application of fiduciary obligations, which proscribe trustees of assets from acting or putting themselves in positions that potentially conflict with the beneficiaries' interests. ${ }^{179}$ The operation of private law ensures that beneficiaries can bring private actions in contract or trust for the breach of terms of the investment management mandate, although not for a disappointment in investment outcomes, which are usually not guaranteed in the mandate. Further, beneficiaries can also bring actions for breach of fiduciary obligations where trustees profit from their positions or have in other ways acted in conflict of interest against their beneficiaries. ${ }^{180}$

The ex post nature of private law enforcement may on the one hand be regarded as proportionate for monitoring the outworking of investment management mandates as, after all, investment performance can only be ascertained with certainty with the lapse of the stipulated horizons. But on the other hand, such ex post mechanisms may be regarded as insufficient for investor protection, as ongoing monitoring is hard to achieve and private litigation at the end of a disappointed mandate may be expensive. These problems are especially acute in collective investment management where individuals may be relatively unsophisticated or unable to afford or access private litigation actions.

The rise of policy-making in investor protection has therefore coincided with the rise of the social scale of investment and collective investment management. The first regulations in investor protection can be traced back to New Deal regulations introduced in the US in the wake

179 Matthew Conaglen, 'The Nature and Function of Fiduciary Loyalty' (2005) 121 L.Q.R. 453; Robert Flannigan, 'The Core Nature of Fiduciary Accountability' (2009) New Zealand Law Review 375.

180 See discussion in Timothy Spangler, The Law of Private Investment Funds (Oxford: OUP 2010); Lodewjik van Setten, The Law of Institutional Investment Management (Oxford: Oxford University Press 2009). 
of the Great Depression, in order to provide investor protection in securities investments through harmonised standards of issuer disclosure. ${ }^{181}$ In the UK, investor protection regulations have been only slowly adopted in harmonised standards ${ }^{182}$ and in conduct of business regulation of investment intermediaries. ${ }^{183}$ However, the rise of regulatory capitalism ${ }^{184}$ in investment management is marked, perhaps as a response to the now widely accepted socio-economic model of financialised collective investment management.

The rise of regulation over securities and then investment funds arguably legitimises the ethos of financialisation - i.e. that investment as a means of saving can be regarded as a 'proper' channel as public regulatory law provides a framework for it and therefore induces a sense of confidence for social participation. The existence of regulatory regimes, premised upon re-assuring objectives of investor protection, arguably induces citizenry to buy the case of widespread social acceptance of risk-bearing by citizenry in investment markets. Further, regulation introduces standardisation that not only reduces transaction cost to access, but also induces a sense of comfort in being governed by these standardised terms of investor rights and protection. Most recently in the UK, as will be discussed in Chapter 4, regulation has also achieved the ultimate legitimation of a key aspect of financialisation - making private pensions saving mandatory. Regulation may thus even culminate in having a constituting effect upon financialisation, by making a key aspect of it a staple of socio-economic life, i.e. saving for the long-term to retirement through private investment markets.

181 The Securities Act 1933 and Securities Exchange Act 1934.

182 Largely under the auspices of EU harmonisation of securities regulation since the 1970s such as Admissions and Listing Particulars Directives, 1979 and 1980 respectively.

183 Largely self-regulatory until the 1990s when the Securities Investment Board produced high level principles, and subsequently taken over by the Financial Services Authority which introduced more regulation, in coincidence with regulatory harmonisation in the EU, see Markets in Financial Instruments Directives 2004, 2014recast.

184 John Braithwaite, Regulatory Capitalism (Cheltenham: Edward Elgar, 2008); David Levi-Faur, 'The Global Diffusion of Regulatory Capitalism' (2005) 598 ANNALS of the Academy of Political Science 12. Regulatory capitalism is the view that regulation is a necessary complement to markets, and that ' $\mathrm{t}] \mathrm{he}$ state is embedded in the economic and social order; any change in the state is expected to be reflected in the economy and the society, and vice versa.', see Levi-Faur above at p. 21. 
Nevertheless, the standardisation effects of regulation in certain aspects of investor protection may change the incentives of investment management and result in unintended consequences. In Chapter 2, we will discuss how two key aspects of investor protection, in regular accountability and liquidity provision, impact upon the internal governance of investment funds, contributing to tendencies that may in turn undermine investor expectations. The role of regulation is therefore a difficult one in achieving a balance of objectives and interests.

First, regulation has provided standardisation in the accountability cycles and content that investment funds should adhere to. These regulatory duties in accountability, to a certain extent, mitigated the disparity in bargaining power between beneficiaries and funds. However, regulatory frameworks that conformed to neo-liberal ideologies may not have been optimally useful for investors/savers, as they favoured minimal regulatory intrusion for fear of limiting choice to savers, and individual responsibility on the part of savers. ${ }^{185}$ That is until the global financial crisis of 2007-09 ushered in more protective frameworks and standards. ${ }^{186}$

Standardised regular accountability regimes are imposed whether investment funds have a long management horizon, such as in pensions, or shorter horizons, such as in other retail collective investment funds (or mutual funds). Such regular accountability addresses 'agency' problems perceived by regulators, as funds are forced to report on the ongoing performance of their investment management on a regular basis, to be scrutinised by investors, so that early issues may be addressed without waiting for ex post private law mechanisms to materialise. However, it remains uncertain how useful such regular accountability is to savers who may not be able to appraise the financial information disclosed. It is uncertain too how they should exercise discipline as savers are too disparate to make their voices heard, and private litigation seems premature and too expensive. Regulatory regimes seem to substitute regulatory enforcement for enforcing savers' interests, but it is queried

185 See Chapter 11, Mads Andenas and Iris H-Y Chiu, The Foundations and Future of Financial Regulation: Governance for Responsibility (Oxford: Routledge 2014).

186 The US Dodd-Frank Act 2009 and the EU regulatory initiatives in this area such as the MiFID II recast Directive 2014, the Alternative Investment Fund Managers Directive 2010, and the UK FCA's many thematic reviews of the market for various investment products such as the unit-linked fund sector, the life insurance sector, endowment mortgages and trade finance. 
whether such compliance only compels unintended consequences contrary to savers' needs.

As regular accountability of investment management performance compels regular valuations whether or not those correspond with the ultimate liabilities of funds in maturity payouts, this could cause funds to be managed for compliance purposes, to meet the needs of the yearly or half-yearly performance accountability report instead of being managed with the ultimate needs of the fund in mind. We are of the view that the needs of 'investor protection', which is defined according to the agency problem, and hence framed around regular monitoring and accountability, could give rise to short-termist myopia on the part of funds. This model of investor protection also seems to cater for the 'hyper-anxious' investor, instead of a more balanced model of the 'trusting' investor ${ }^{187}$ whose vision is fixed on the ultimate maturity of the mandate. The pressures of short-term transparency could drive funds towards desperate searches for yield, excessive transactionalisation and investment management practices that try to 'squeeze out' as much as possible from assets rather than participate in a constructive long-term wealth creation process with business. The need for investor protection on an ongoing basis has become standardised by regulation, and has therefore become a matter for compliance. The regulatory framework could be in conflict with the objectives of patient investment fund management that delivers to meet the liabilities over the longer stipulated term, such as in pensions.

However, we observe that such standardisation in frequency and content of investment fund accountability is proliferating across fund structures, from pensions to collective investment funds, to alternative investment funds. This has been led by EU level legal harmonisation ${ }^{188}$ which couples fund regulation issues with market access, i.e. allowing market access only on the basis of compliance with EU-wide harmonised regulation. Market access and the building of an integrated EU market has exacerbated standardisation pressures in regulation, but it needs to be queried whether such regulatory frameworks produce unintended effects in the practices of investment management.

Short-termist myopia in investment funds has become an important aspect of investment management, and may be manifest in different ways - from neglect of their corporate governance roles in equity investments,

187 Advocated in Niamh Moloney, How to Protect Investors; Lessons from the EC and the UK (Cambridge: Cambridge University Press 2012).

188 Undertakings in Collective Investments in Transferable Securities Directive 2009 recast as amended in 2014; Alternative Investment Fund Managers Directive 2011. 
focusing only on trading, to being actively engaged for 'value extraction' from investee companies, ${ }^{189}$ albeit for a relatively fixed term. Hence, the corporate governance roles of funds are not a phenomenon divorced from their internal governance, structures and incentives, and can only be appraised against that backdrop in order to ascertain what value they add - in terms of sustainable and successful investment performance for their term of mandate and in constructive participation in the wealth-creating role of business for the economy and society.

Further, we are also of the view that the needs of investor liquidity also drive, to a large extent, the internal governance of funds, and this area is becoming more and more important in regulatory policy. When investors may be able to redeem their investments may be a matter of private contract, but in retail investments, liquidity for investors is highly prized as liquidity reduces the contracting cost for investors who are less certain of their commitment horizons. Even if an investor's investment horizon is not particularly short, an investor may prefer to be able to cash out of an investment at short notice. The availability of liquidity induces a sense of safety. Further, investors' preference for liquidity may be attributed to the appeal of potential ease in reallocating capital in this age of choice in global investment opportunities. ${ }^{190}$ Whether we characterise investors' preference for liquidity as being short-sighted and lacking in loyalty or as

189 'Value extraction' is a term that offensive activists such as hedge funds often use to describe their investment strategies in shareholder activism. It is based on a belief that the company's share price does not currently reflect what the price ought to be, and that activists may be able to offer suggestions which, if taken by the company, would allow the market to revalue the share price of the company positively. See also remarks made by Eric Knight, Knight Vinke at Shareholder Activism in the UK, a conference held in London, 16 Oct 2008.

190 However, many commentators urge a nuanced understanding of global mobility of capital. For example, Williams argues that geographical limitations to such mobility may still occur due to market preferences such as home bias or political economy contexts. Colin C Williams, 'A Borderless World Of Hypermobile and Homeless Money?' (2004) 2 Industrial Geographer 144. Further, journalistic evidence seems to bear out preferences for greater mobility during boom times and withdrawal during uncertain times, see 'Emerging Markets in Retreat', edited by the Financial Times (1 Feb 2015); Suxiao Li, Jakob de Haan, Bert Scholtens and Haizhen Yang, 'Are International Fund Flows Pro- or Counter-Cyclical?' (2015) 22 Applied Economics Letters 378. Watson also argues that mobility of capital need not mean spatial mobility, but fungible mobility i.e. the transformation of capital into different risk forms due to the possibilities of financial innovation in hedging and chasing returns, see Matthew Watson, The Political Economy of International Capital Mobility (Basingstoke: Palgrave Macmillan 2007) at Chapters 2 and 3. 
being hyper-mobile, necessarily transient and efficient, the need for liquidity has fed into investment management practices and regulatory frameworks. As such, harmonised European law has reinforced such investor preferences by mandating such redemptions to be offered regularly, at least twice a month in relation to mutual funds, and funds generally offer daily redemptions. Although alternative investment funds, such as hedge funds and private equity, remain free to stipulate their redemption terms, regulation has mandated regular and independent valuations in order to support investor protection. The needs of liquidity support transactionalisation and trading as being key tenets of financialised investment management.

The perceived need for liquidity has however been criticised by Kay 191 who regards this perceived need as being exaggerated by the financial sector, as underlying beneficiaries do not have such frequent and large scale liquidity needs. Further, funds have also engaged in financial innovation to 'liquefy' investment choices even if underlying assets are less liquid, such as in exchange-traded funds, as will be discussed in Chapter 5. Such financial innovation has been motivated on the demand side by investors' search for yield and on the supply side by investment funds keen to attract more inflows. However, there are hidden dangers ${ }^{192}$ in assetisation strategies that involve 'liquefying' relatively less liquid assets.

Although, on the one hand, funds may be driven by short-termist and liquidity pressures, on the other hand such pressures also open up opportunities in financial innovation and the marketisation of finance, and increase prospects of appeal and profitability of the financialised investment management model. ${ }^{193}$ Hence, the supporting law and regulatory frameworks are likely welcomed by the investment management sector. More recent changes in regulatory thinking, such as systemic importance and long-termist fund management, may indeed introduce anxieties for the sector.

The next Section turns to why investment funds own corporate equity and the enduring importance of equities as an asset class. This Section also looks at how the rubric of shareholder rights and corporate governance roles forms part of the appeal of equity investment.

\footnotetext{
191 John Kay, Other People's Money (2015) above at pp. 87-95.

192 'ETFs to play main role in next crisis', Financial Times (28 Dec 2015).

193 Kathryn Judge, Intermediary Influence (2015) 82 University of Chicago Law Review 573.
} 


\section{E. IMPORTANCE OF EQUITIES AS AN ASSET CLASS}

Equities are a key asset class for all of the collective investment entities discussed in this book. ${ }^{194}$ The dedicated portfolio of 60 per cent stocks and 40 per cent bonds ${ }^{195}$ has become a standard in many pension fund allocations for example. Equities are favoured for return purposes. Although market prices in stock are subject to a certain degree of unpredictability, historical analyses have consistently shown that returns on equities exceed fixed income holdings. This is known as the 'equity premium'. ${ }^{196}$ It may be argued that much research conducted on the equity premium had been carried out in the 1980s and 90s and hence was based on stock price data that spanned a significant bull run period in the 1980s. If so, it could be questioned whether the equity premium would still hold over a much longer time-span, through different market and economic cycles. Malagoli and Young ${ }^{197}$ seem to suggest that the equity premium would hold if stocks were purchased in trough times and therefore under-valued, and held through good cycles. Depending on the timing of purchase and the period of holding, the equity premium may not be significantly higher over fixed income returns. However, more recent research ${ }^{198}$ suggests that the equity premium is an enduring phenomenon, especially over the long term. Short termist holdings of equities may not outperform fixed income in trough cycles but riding out cycles will yield an overall superior performance to fixed income. Hence, equities are likely to persist as a favoured asset class whether by collective investment entities managing pensions and retail funds or alternative funds.

194 This is borne out by empirical survey, see FCA, Asset Management Market Study (Nov 2015) at para 3.16.

195 Martin L Leibowitz, 'The Dedicated Bond Portfolio in Pension Funds Parts 1 and 2' (1986) 42 Financial Analysts Journal 68-75 and 47-57 respectively.

196 Roger G Ibbotson, Richard C Carr and Anthony W Robinson, 'International Equity and Bond Returns' (1982) 38 Financial Analysts Journal 61; Rajnish Mehra and Edward C Prescott, 'The Equity Premium: a Puzzle' (1985) 15 Journal of Monetary Economics 145-162; taken stock of in Pablo Fernandez, 'The Equity Premium in 150 Textbooks' (2013) at http://papers.ssrn.com/sol3/ papers.cfm?abstract_id=1473225.

197 Andrea Malagoli and Chris Young, 'Stocks for the Long Run: Historical Facts and Statistical Fallacies' (2010) at http://ssrn.com/abstract=1904992.

198 Michael W Crook and Brian Nick, 'Equities (still) for the Long Run: A New Look at the Future Equity Premium' (2012) at http://ssrn.com/abstract= 2172796. 
Further, the supply of new publicly traded equity is likely to increase as the global market for listed capital is expected to grow. ${ }^{199}$ Fund-raising in public equity markets remains an important avenue in corporate finance despite the high costs of listing in the premium markets of the world. Equity finance may be raised to an extent surpassing what debt or retained earnings in firms could contribute for growth and expansion purposes and offers a permanent and stable form of finance. ${ }^{200}$ The foray into raising public equity may be regarded by many firms as a stage of maturation in business, ${ }^{201}$ and is important for reputational and branding benefits. ${ }^{202} \mathrm{~A}$ couple of commentators ${ }^{203}$ opine that the opportunities for growth for firms are unlikely to be pursued in the absence of raising funds from public equity markets, and block-holders in private companies such as family-owned and controlled businesses would rather dilute their equity in order to be able to capture the potential of growth opportunities. Although there has been a trend of private equity investment in firms in order to avoid the costs of public flotation and the constraints imposed on firms due to listing and regulatory rules, ${ }^{204}$ private equity funds have certain investment horizons and need to exit their investments at some point in time. Such exit is usually through a sale to another private equity or through public flotation. Even the firms

199 See Price Waterhouse Coopers, US Global Equity Watch 2012 reporting growth in initial public offers, and the impact of the US JOBS Act; Europe IPO Watch Q1 2014 also reports increasingly vibrant activity after a slow-down experienced during the global financial crisis.

200 C Fritz Foley and Robin Greenwood, 'The Evolution of Corporate Ownership after IPO: The Impact of Investor Protection' (2010) 23 Review of Financial Studies 1231; Price Waterhouse Coopers and Baker \& McKenzie, Cross-border IPOs: Choice in an Uncertain World (Nov 2012) at http:// www.pwc.com/en_GX/gx/audit-services/ipo-centre/assets/pwc-cross-border-ipotrends.pdf.

201 Julian Franks, Colin Mayer, Paolo Volpin and Hannes F Wagner, 'The Life Cycle of Family Ownership: A Comparative Study of France, Germany, Italy and the UK' (2012) 25 Review of Financial Studies 1675.

202 Gaia Marchisio and Davide Ravasi, 'Family Firms and the Decision to Go Public: A Study of Italian IPOs' (2001) at http://ssrn.com/abstract=278237.

203 Marco Becht and J Bradford Delong, 'Why Has There Been So Little Block Holding in America?', in Randall Morck (ed.), A History of Corporate Governance around the World at 613; C Fritz Foley and Robin Greenwood, 'The Evolution of Corporate Ownership after IPO: The Impact of Investor Protection' (2010) 23 Review of Financial Studies 1231.

204 Ronald J Gilson and Charles K Whitehead, 'Deconstructing Equity: Public Ownership, Agency Costs, and Complete Capital Markets' (2008) 108 Columbia Law Review 231. 
that have been taken private from public by private equity look towards eventual flotation in due course. ${ }^{205}$

Publicly traded equity would remain a key and enduring asset class for investment fund entities as it is also supported by good market infrastructure in many developed economies - established stock exchanges supported by systems of securities regulation. ${ }^{206}$ These are important conditions for attracting investors and keeping the markets liquid. ${ }^{207}$ In the European Union, the Financial Services Action Plan 1999 (that kickstarted a legislative harmonisation process for prospectus disclosures by firms intending to go public and transparency obligations for firms listed on securities markets) put in place an infrastructure that could be uniformly implemented across the EU, 208 in both the developed and emerging economies. Some asset classes are not as well-supported by developed markets, such as corporate bonds, certain securitised assets as observed in the global financial crisis, exotic asset classes such as art and wine (although international auction houses play an important role) and infrastructure.

Further, many premium stock exchanges have second tier markets ${ }^{209}$ that cater for smaller business listings at lower cost and supported by less demanding rules that attempt to strike a balance between an appropriate level of investor protection and providing corporate finance access to firms. Opportunities for cross-listing and foreign listing have also become more and more accessible. For example, cross-listing in the EU

205 E.g. Elizabeth Rigby, 'Inside the Debenhams deal', Financial Times (5 Aug 2007).

206 Bernard S Black, 'The Legal and Industrial Preconditions for Strong Stock Markets' (Stanford Law School Working Paper No. 179, 2001); Price Waterhouse Coopers and Baker \& McKenzie, Cross-border IPOs (2012), above. 207 Branding thesis, Layna Mosley and David Andrew Singer, 'Taking Stock Seriously: Equity-Market Performance, Government Policy, and Financial Globalization' (2008) 52 International Studies Quarterly 405.

208 The Prospectus Directive 2003 (European Parliament and Council Directive 2003/71/EC of 4 November 2003 on the prospectus to be published when securities are offered to the public or admitted to trading and amending Directive 2001/34/EC [2003] OJ L345/64) amended as of 2010; the Transparency Directive 2004 (European Parliament and Council Directive 2004/109/EC of 15 December 2004 on the harmonisation of transparency requirements in relation to information about issuers whose securities are admitted to trading on a regulated market and amending Directive 2001/34/EC [2004] OJ L390/38) amended as of 2014.

209 Such as the Alternative Investment Market in London, the Alternext market operated by Euronext. 
is facilitated by the EU prospectus passport brought in place by legislative harmonisation. ${ }^{210}$ Globalisation and the global competition of capital markets has also made cross-listing possible and attractive since the 1990s. ${ }^{211}$ Firms in emerging economies that may not be able to seek sufficient capital on home turf could seek cross-border capital and embark on growth and maturation on a global stage. In this respect, the privatisation of state-owned companies in many emerging economies is often completed through a flotation process of dispersal of equity. Such privatisations have also been reported to be important to improving future performance of state-owned firms, ${ }^{212}$ and at a broader level are a key step in the liberation and development of emerging economies. ${ }^{213}$ Crossborder equity raising is also becoming more well-accepted as the equity home bias is disappearing ${ }^{214}$ in the broader context of global trade liberalisation - increases in cross-border activity and improvements in information technology that help to overcome information asymmetries. Hence, publicly traded equity as an asset class will continue to cater for both an expanding supply and a demand base at a global level.

210 The Prospectus Directive 2003 (European Parliament and Council Directive 2003/71/EC of 4 November 2003 on the prospectus to be published when securities are offered to the public or admitted to trading and amending Directive 2001/34/EC [2003] OJ L345/64) amended as of 2010.

211 See Uri Geiger, 'The Case for the Harmonisation of Securities Disclosure Rules in the Global Market' (1997) 1997 Columbia Business Law Review 241, Price Waterhouse Coopers and Baker \& McKenzie, Cross-border IPOs (2012), above.

212 Seung-Doo Choi, Inmoo Lee and William Megginson, 'Do Privatization IPO Firms Outperform in the Long Run?' (2006) at http://ssrn.com/abstract= 676181.

213 Franklin Allen, Jun Q J Qian, Susan Chenyu Shan and Mengxin Zhao, 'The IPO of Industrial and Commercial Bank of China and the 'Chinese Model' of Privatizing Large Financial Institutions' (2012) 20 European Journal of Finance 599.

214 Amir A Amadi, 'Equity Home Bias: A Disappearing Phenomenon?' (2004) at http://papers.ssrn.com/sol3/papers.cfm?abstract_id=540662. See also Darius Wójcik, 'The Role of Proximity in Secondary Equity Markets' in Gordon L Clark, Adam D Dixon and Ashby H B Monk (eds), Managing Financial Risks: From Global to Local (Oxford: OUP 2012) at Chapter 6, arguing that the home bias still makes sense as local information may be more readily available to proximate investors (due to soft information, presence of local financial intermediaries) and investors feel more charitable towards domestic issuers. But foreign equities supported by harmonisation of information reporting standards, visibility marketing campaigns and foreign expert intermediaries who also have a local presence could also become very attractive. 
That said, the nature of publicly traded equity is not necessarily dispersed public equity. Much of publicly traded equity, and even a proportion in the US and UK (two countries that have pronounced dispersed ownership patterns in a majority of publicly traded firms), is a minority stake sitting alongside block-held stakes by states or families. It is noted that the corporate governance issues surrounding block-holders have been raised in relation to countries where block-holders are the norm, ${ }^{215}$ and also in the $\mathrm{UK}^{216}$ and US. ${ }^{217}$ Institutional investors and listing authorities are however working towards securing acceptable standards of investor protection in a variety of different firm governance structures $^{218}$ and the appeal of publicly traded equities as an asset class would likely be undiminished.

Owners of equities enjoy the usual proprietary rights of dealing and creating security, and governance rights such as rights of participation and voting in publicly traded companies. Such governance rights have been reserved for equity holders and do not extend to other stakeholders on the basis of commitment of capital as a residual claim. ${ }^{219}$ Although shareholders' rights are expressed as 'reserve' power in the UK, ${ }^{220}$ certain powers are the exclusive province of the general meeting such as removal of directors, ${ }^{221}$ amendment of constitution, ${ }^{222}$ of substantial transactions, ${ }^{223}$ ratification of directors' breaches and most recently, a 3-yearly

215 E.g. Stijn Claessens, Simeon Djankov, Joseph P H Fan and Larry H P Lang, 'Expropriation of Minority Shareholders: Evidence from East Asia' (2004) at http://elibrary.worldbank.org/doi/book/10.1596/1813-9450-2088; Meijun Qian, Hongbo Pan and Bernard Yin Yeung, 'Expropriation of Minority Shareholders in Politically Connected Firms' (2010) at http://papers.ssrn.com/sol3/papers.cfm ?abstract_id=1719335.

216 Financial Conduct Authority, Enhancing the Effectiveness of the Listing Regime and Further Consultation (November 2013); Response to CP13/15 Enhancing the Effectiveness of the Listing Regime (May 2014).

217 E.g. 'Activist urges fix for Silicon Valley', Financial Times (23 April 2014).

218 Roger Barker and Iris H-Y Chiu, 'Protecting Minority Shareholders in Blockholder-Controlled Companies - Evaluating the UK's Enhanced Listing Regime in Comparison with Investor Protection Regimes in New York and Hong Kong' (2015) Capital Markets Law Journal, forthcoming.

219 See discussion and citations in Chapter 4, Iris H-Y Chiu, The Foundations and Anatomy of Shareholder Activism (Oxford: Hart, 2010).

220 Article 4, Model Articles of Public and Private Companies Limited by Shares.

221 S168, Companies Act 2006.

222 S21, Companies Act 2006.

223 Ss190-200, Companies Act 2006. 
binding vote on director remuneration packages. ${ }^{224}$ With increased publicly listed equity and the dispersal of equity observed in large corporations in the 1930s, Berle and Means have already wondered 225 if the proprietary rights that are conferred on public equity owners should remain the same as those conferred on equity owners who are involved in managing privately-held companies. They were of the view that dispersed public equity owners were likely to be passive and uninterested investors who would focus on dealing on the capital markets. The removal of special property rights from them would then allow corporations to be managed as social institutions for wider societal interest. The point was never taken up in public policy, and corporate law moved away from social and communitarian concerns into individualistic and efficiency concerns. ${ }^{226}$ This was a natural development given the wider political backdrop of rising unpopularity of socialist-type rhetoric.

Berle and Means' prediction of the behaviour of equity owners held true for a long time. Shareholders in publicly traded companies treated equity assets as investments to be bought or sold for market gains whether in the short term or over longer periods. ${ }^{227}$ Dissatisfaction with companies was expressed through exit i.e. selling of shares. In fact, the appeal of equity investment could also lie in being able to exit in the market for corporate control, as takeover premia would generate positive short-term investment performance for shareholders. The governance attributes of equities as part of the bundle of 'ownership' rights were largely ignored by institutional investors. ${ }^{228}$ The sidelining of governance rights by institutional investors in publicly traded equity was due to the relative ease of engaging in trading activities which cost less and more easily realised investment gains. However, taking the perspective of equities as commodified assets in the era of financialisation, the attributes of ownership of equity are constantly being evaluated and exploited in

224 S226B, Companies Act 2006 inserted by s80, Enterprise and Regulatory Reform Act 2013.

225 See Adolf A Berle and Gardiner C Means, The Modern Corporation and Private Property (NY: Macmillan, 1932), p. 66.

226 Dalia Tsuk, 'From Pluralism to Individualism: Berle and Means and 20th-Century American Legal Thought: The Modern Corporation and Private Property by Adolf A. Berle, Gardiner C. Means Review' (2005) 30 Law and Social Inquiry 179.

227 Lynne Dallas, 'Short-Termism, the Financial Crisis, and Corporate Governance' (2012) 37 Journal of Corporation Law 265.

228 Bernard S Black, 'Shareholder Passivity Re-examined' (1990) 89 Michigan Law Rev 520; John C Coffee, 'The Folklore of Investor Capitalism' (1997) 95 Michigan Law Review 1970. 
order to generate investment gains. Hence, hitherto ignored governance rights could become important to investors if they relate to the potential for investment gains. Such an instrumental approach to corporate governance has been observed in contemporary shareholder activism since the 1990s, as shareholder activism began to arise in corporate America led by public sector pension funds such as CalPERS. ${ }^{229}$ Shareholders have started to become engaged with their governance rights as the exploitation of these could relate to financial outcomes and improved investment gains. Hedge fund activism, a more recent phenomenon which will be discussed in Chapter 6, is an almost extreme example of the instrumental approach. The publicisation of hedge fund stakes in companies of a significant threshold, such as at 1 per cent and above, would immediately trigger a stock price response upwards. ${ }^{230}$ The earning potential of being engaged in governance has in some cases become a self-fulfilling prophecy.

This book argues that the instrumental approach to corporate governance reflects the financialised character of investment management as a form of financier capitalism. Commentators have earlier positively welcomed institutional engagement with their corporate governance rights and roles. Institutional engagement could compel the development and cascading of better governance standards for companies and result in improvement in corporate performance. ${ }^{231}$ Hawley and Williams ${ }^{232}$ also see the potential for institutional investor capitalism becoming a beacon for the development of global standards for better governed companies, extending to wider social responsibility and sustainability issues. There is some faith in intermediary institutions serving as representatives of the

229 See Chapter 1, Iris H-Y Chiu, The Foundations and Anatomy of Shareholder Activism (Oxford: Hart, 2010).

230 Alon A Brav, Wei W Jiang, Randall S R S Thomas and Frank F Partnoy, 'Hedge Fund Activism, Corporate Governance and Firm Performance' (2007) at $<$ http://ssrn.com/abstract=948907; Marco Becht, Julian Franks, Jeremy Grant and Hannes F Wagner, 'The Returns to Hedge Fund Activism: An International Study' (2014) at http://papers.ssrn.com/sol3/papers.cfm?abstract_id=2376271.

231 Alfred F Conard, 'Beyond Managerialism: Investor Capitalism?' (19881989) 22 U. Mich. J.L. Reform 117.

232 J P Hawley and A T Williams, 'Shifting Ground: Emerging Global Corporate-Governance Standards and the Rise of Fiduciary Capitalism' (2005) 37 Environment and Planning 1995-2013, The Rise of Fiduciary Capitalism: How Institutional Investors Can Make Corporate America More Democratic (University of Pennsylvania Press, 2000) generally. 
saving masses in revolutionising corporate governance for the better. ${ }^{233}$ On the other hand, shareholder activism could kickstart corporate asset sales, takeovers or mergers and return of capital, decisions that are less unequivocally beneficial for the companies and their relevant stakeholders. The incentives that underlie the instrumental approach to corporate governance often encourage myopic forms of profit seeking, selfish forms of exploitation and little regard for non-value denominated concerns. In this book, we argue that investment funds' corporate governance roles are necessarily an instrumental facet of their investment management, which has a financialised character and is shaped by pressures of global competition and regulatory frameworks. We will draw out the implications for their roles in the intermediation of savings and investment and in long-term wealth creation of the corporate economy. ${ }^{234}$ The next chapter now turns to the common themes in the internal governance, structures and incentives for funds.

233 Gordon L Clark, Pension Fund Capitalism (Oxford: Oxford University Press, 2000); Gordon L Clark and Tessa Hebb, 'Why Should They Care? The Role of Institutional Investors in the Market for Corporate Global Responsibility' (2005) 37 Environment and Planning 2015; Stuart L Gillan and Laura T Starks, 'Corporate Governance, Corporate Ownership, and the Role of Institutional Investors: A Global Perspective' (2003) 13 Journal of Applied Finance 4; Tessa Hebb, No Small Change: Pension Funds and Corporate Engagement (Ithaca NY: Cornell University Press, 2008).

234 Riccardo Bellofiore, 'The Ascent and Crisis of Money-Manager Capitalism' (2011) 40 International Journal of Political Economy 5. 